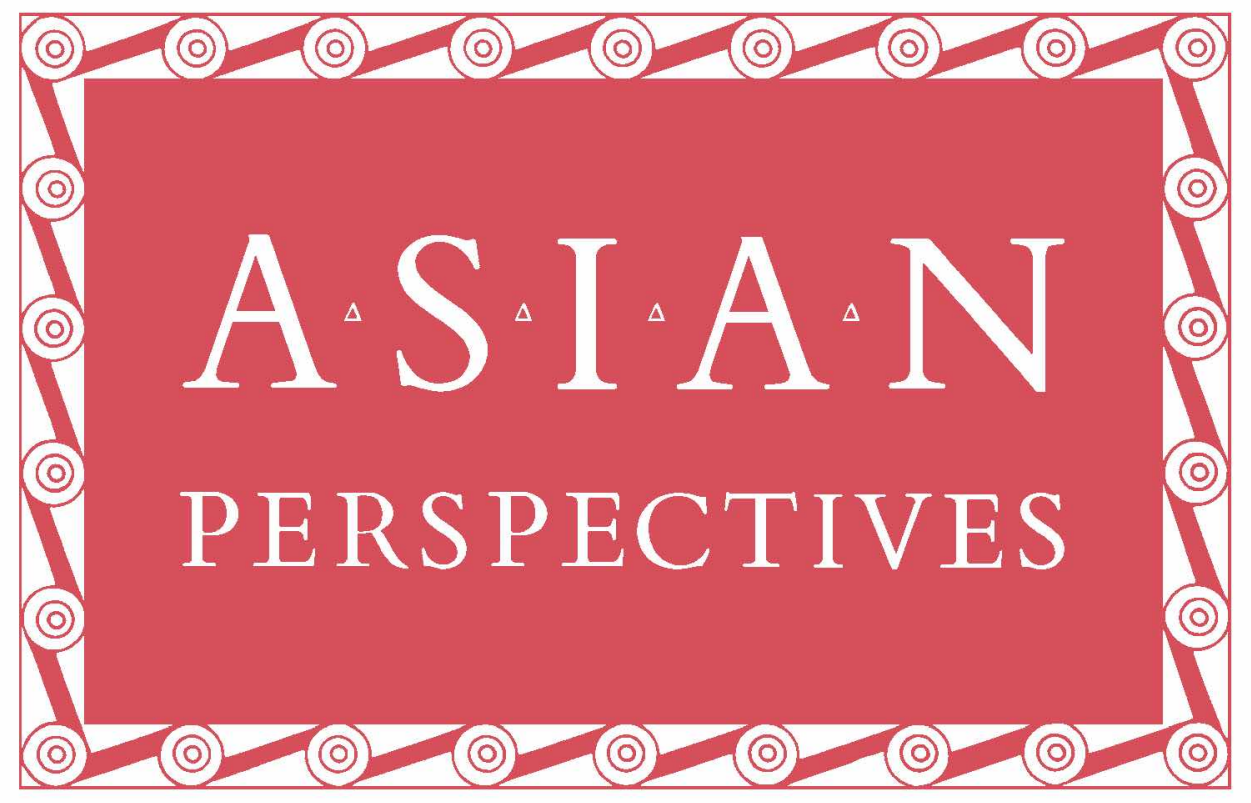

The Journal of Archaeology

for Asia and the Pacific

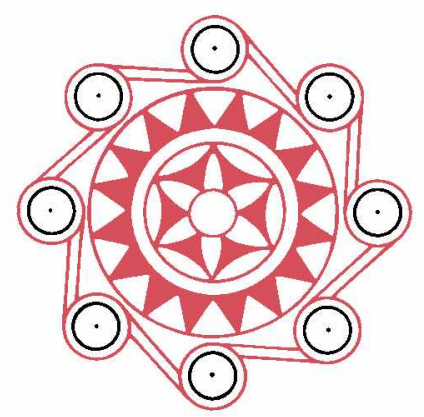

Volume 59 Number 12020 


\section{ASIAN PERSPECTIVES}

The Journal of Archaeology for Asia and the Pacific

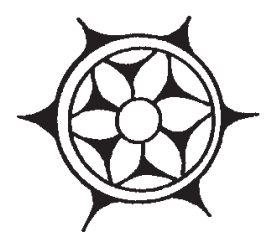

Editors' Note

ARTICLES

Formation and Function of Majiayao and Qijia Pottery:

Analysis of Manufacturing Marks and Use-alteration on

Vessels from the Tao River Valley

Andrew WOMACK and Hui WANG

Revisiting Prei Khmeng: The Excavation of an Iron Age

Settlement and Cemetery in Cambodia

Dougald O'Reilly, Louise Shewan, Kate Domett, and $A n$ SOPHEAP

Traditional Land Use and Resistance to Spanish Colonial

Entanglement: Archaeological Evidence on Guam

Boyd Dixon, Danny Welch, Lon Bulgrin, and Mark Horrocks

Lapita on Wari Island: What's the Problem?

Merryn Chynoweth, Glenn R. Summerhayes, Anne Ford, and Yo NEGISHI

Integration and the Regional Market System in the Early Chinese Empires: A Case Study of the Distribution of Iron and Bronze

Objects in the Wei River Valley

LAM Wengcheong

Antenna-Style Daggers in Northeast Asia from the Perspective of Interregional Interaction 
Recovering Plant Microfossils from Archaeological and other Paleoenvironmental Deposits: A Practical Guide Developed from Pacific Region Experience

Mark HORROCKS

REVIEW ESSAY

Ban Chiang, Northeast Thailand, Volumes 2A and 2B:

A Review Essay

Charles HIGHAM

BOOK REVIEWS

Empires and Exchanges in Eurasian Late Antiquity:

Rome, China, Iran, and the Steppe, ca. 250-750

Reviewed by Barry CUNLIFFE

Violence, Kinship and the Early Chinese State:

The Shang and their World

Reviewed by WANG Haicheng

Silk, Slaves, and Stupas: Material Culture of the Silk Road

Reviewed by Toby C. WILKINSON

OBITUARIES

Martin Thomas Bale (1970-2018)

Rachel LEE and Mark BYINGTON

Hung Ling-yu (1975-2018)

Tristram R. KIDDER and Sara FRIEDMAN 


\title{
Revisiting Prei Khmeng: The Excavation of an Iron Age Settlement and Cemetery in Cambodia
}

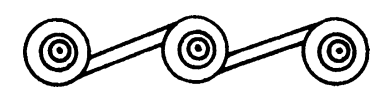

\author{
Dougald O’Reilly, Louise Shewan, Kate Domett, and An SoPheaP
}

\begin{abstract}
Prei Khmeng, a village $13 \mathrm{~km}$ northwest of Siem Reap, Cambodia, is noted for the presence of one of the region's earliest monuments, Prasat Prei Khmeng. Aside from its ruined temple, Prei Khmeng is an important prehistoric occupation site that immediately pre-dates the foundation of the temple. First excavated by a Franco-Cambodian team in the early 2000s, the site was revisited in 2014 by an Australian-Cambodian research team. Recent research revealed Iron Age domestic occupation as well as inhumation burials. The burial assemblage provides evidence of regional trade and exchange and mortuary wealth differentiation. Bioarchaeological examination of the individuals interred at the site reveals intentional dental modification and perimortem blunt and sharp force skeletal trauma. This research sheds light on this important epoch in prehistory, a juncture between the prehistoric and protohistoric period in Cambodia, which was a time of substantial socio-political transformation. KEYwORDS: cemetery, bioarchaeology, prehistory, Iron Age, Cambodia, Angkor.
\end{abstract}

\section{INTRODUCTION}

Prei Khmeng village $\left(13^{\circ} 25^{\prime} 38.39^{\prime \prime} \mathrm{N}, 103^{\circ} 45^{\prime} 28.41^{\prime \prime} \mathrm{E}\right)$ is located southwest of the Western Baray in Siem Reap province, Cambodia. The site and ruined brick temple of the same name has long attracted the interest of archaeologists. It was first documented by Lunet de Lajonquière (1911) in the early twentieth century (Fig. 1). In 1933, Trouvé recorded a unique, decorative, door lintel and an inscription (K. 774) at Prei Khmeng (Trouvé 1933). The lintel's distinct artistic traits led de Coral-Rémusat (1940) to define it as the "Prei Khmeng style" of early Angkorian art. The site was first excavated by a Franco-Cambodian team in the early 2000s and was selected for renewed excavation as part of a broader research initiative entitled "From Paddy to Pura: The Origins of Angkor" based on the confirmed presence of prehistoric occupation and the existence of a later early historic period temple on the mound (Pottier, Baty et al. 2003; Pottier, Guerin et al. 2001a; Pottier, Guerin et al. 2001b).

We present here a summary of the excavations at Prei Khmeng with a review of the archaeological stratigraphy and the mortuary contexts encountered, followed by a

Dougald O'Reilly is an Associate Professor at the Australian National University, Canberra, Australia. Louise Shewan is the Centenary Research Fellow at the University of Melbourne, Melbourne, Australia. Kate Domett is an Associate Professor at James Cook University, Townsville, Australia. An Sopheap is a Technical Officer with the APSARA Authority in Siem Reap, Cambodia. 


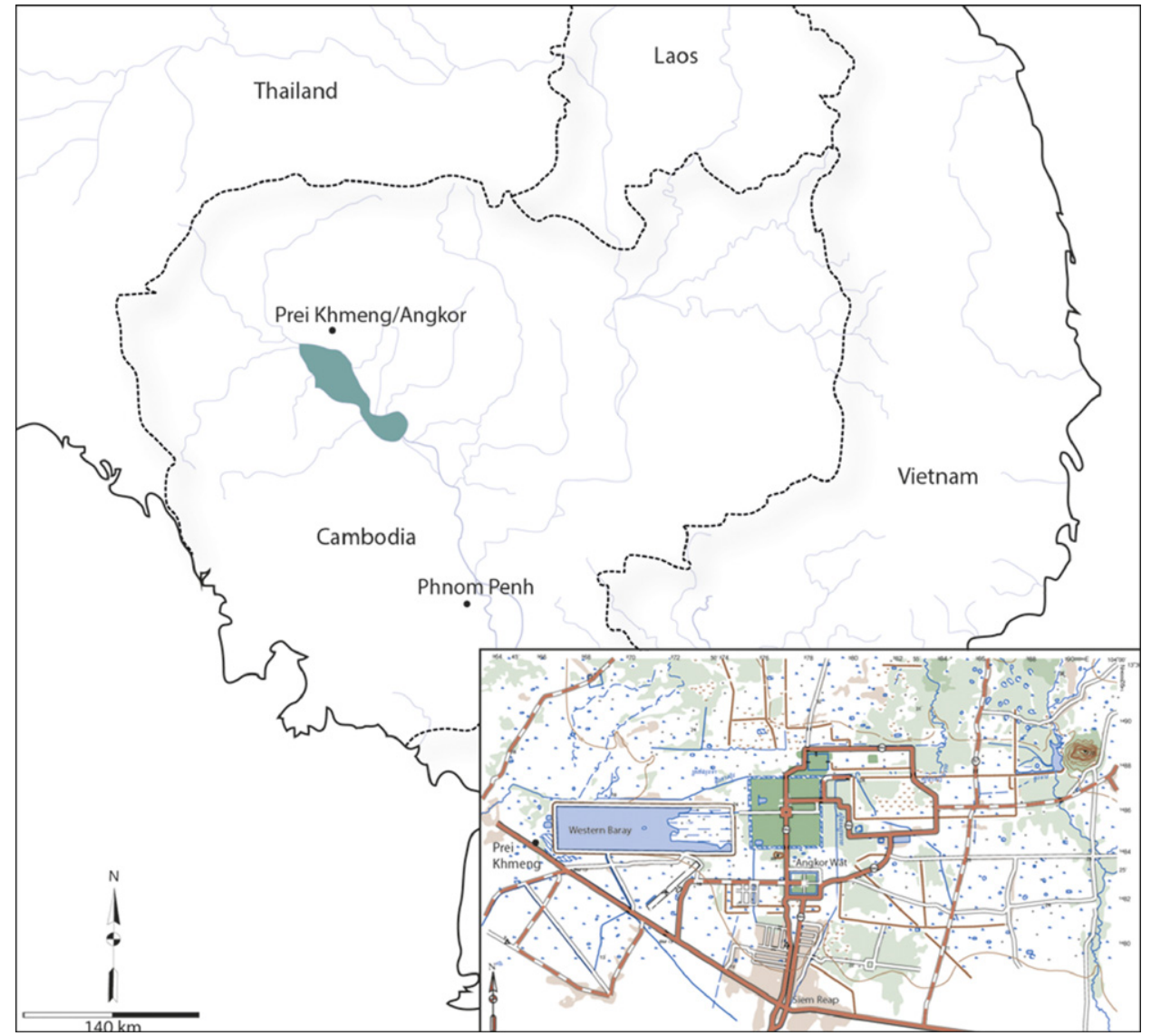

Fig. 1. Map showing location of Prei Khmeng with inset of site in relation to historic features at Angkor (background topographic data courtesy of JICA and NASA-SRTM).

discussion of the importance of Prei Khmeng and its context to the emergence of increasingly complex societies prior to the rise of the Angkor state.

\section{PREVIOUS RESEARCH AT PREI KHMENG}

Between 2000 and 2003, the École française d'Extrême-Orient (EFEO) and the Authority for the Protection and Management of Angkor and the Region of Siem Reap (APSARA) undertook three excavations at Prei Khmeng as part of the Mission Archéologique Franco-Khmère sur l'Aménagement du Territoire Angkorien (MAFKATA). The first MAFKATA excavations at Prei Khmeng in 2000 saw excavation units opened both on the temple mound and to the south of the sanctuary and in the southern moat. In 2001, four units were opened to expand on discoveries made in the first season's excavations. In 2003, four trenches were excavated, all atop the temple mound (Fig. 2). The excavation results are published in French (Pottier, Baty et al. 2003; Pottier, Guerin et al. 2001a; Pottier, Guerin et al. 2001b). The mound on which the temple was built sits atop an Iron Age occupation with evidence for 


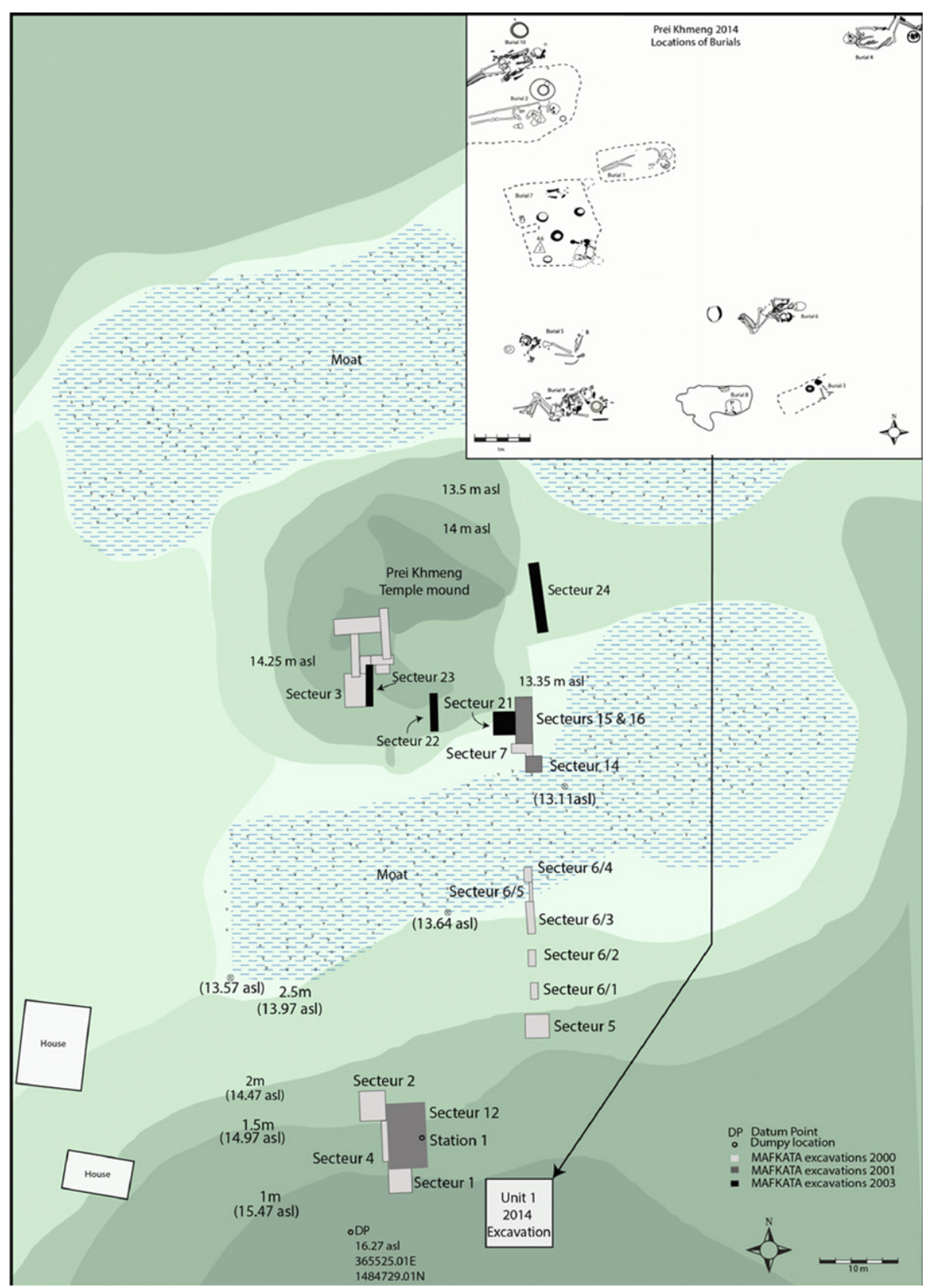

Fig. 2. Map of Prei Khmeng with inset of mortuary contexts (after MAFKATA Topographic survey SRP831, December 2000 [Pottier, Guerin et al. 2001a]).

occupation from the first to sixth centuries A.D. (Penny et al. 2007). The temple mound was found to include human remains and artifacts of Iron Age date, suggesting that the soil from the moat that surrounds the temple was excavated and used to construct the mound on which the temple was built. As Penny and colleagues (2007) note, this created an inverted cultural stratigraphy over the Iron Age layers which was not present 
Table i. Radiocarbon Dates from Prei Khmeng (MAFKATA Excavations)

\begin{tabular}{lcccc}
\hline ANSTO CODE & EFEO CODE & $\begin{array}{c}\text { RADIOCARBON } \\
\text { AGE B.P. }\end{array}$ & $\begin{array}{c}\text { CALIBRATED } \\
\text { AGE RANGE } \\
\text { (I } \delta \text { ) (A.D.) }\end{array}$ & $\begin{array}{c}\text { CAlibRATED } \\
\text { AGE RANGE (2 } \delta \text { ) } \\
\text { (A.D.) }\end{array}$ \\
\hline $\begin{array}{l}\text { First excavation pit (Bony I) } \\
\text { OZF399 }\end{array}$ & PKM00 7007 & $1912 \pm 36$ & $56-133$ & $15-209$ \\
OZF402 & PKM00 7004 & $1538 \pm 36$ & $458-574$ & $433-610$ \\
Second excavation pit (Bony II) & & & \\
OZG006 & PKM1-15021 & $1614 \pm 39$ & $406-513$ & $346-538$ \\
OZG007 & PKM01-15032 & $1815 \pm 38$ & $146-254$ & $98-321$ \\
OZG009 & PKM01-15070 & $1816 \pm 39$ & $100-211$ & $69-248$ \\
\hline
\end{tabular}

Data source: Zoppi et al. 2004.

on the occupation mound outside the moats, indicating that the material excavated from the moat was used in the construction of the temple platform.

The MAFKATA project (Pottier, Baty et al. 2003) reported a number of radiocarbon dates from the excavations (specifically from SU 7007, a human interment) and recorded utilisation of the site from the first to second centuries A.D. (Chhem et al. 2004; Zoppi et al. 2004) (Table 1). Ten interments were uncovered during these excavations; burials higher in the stratigraphy were dated between A.D. 431 and 577 (Pottier, Baty et al. 2003). Dates from the MAFKATA excavations demonstrate a range from ca. A.D. 1 to 650 (as displayed in Pottier, Bolle et al. 2009). ${ }^{1}$ The team interpreted the occupation of the mound as continuous with a succession of sub-phases of occupation and burials lasting to the middle of the seventh century followed by activity dating from the late ninth century to the mid-twelfth century. Dates from the foundation layers of the temple at Prei Khmeng indicate that the temple was erected no later than the first half of the seventh century (Pottier and Bolle 2009).

\section{EXCAVATION METHODOLOGY}

In January 2014, an $8 \times 8 \mathrm{~m}$ unit (Unit 1) was established on the mound of Prei Khmeng village to the south of the temple and moat. This unit was located to the east of the MAFKATA excavation Units 1, 2, 4, and 12 (Pottier, Baty et al. 2003; Pottier, Guerin et al. 2001a; Pottier, Guerin et al. 2001b). The northeast corner of Unit 1 is located at $13^{\circ} 25^{\prime} 64^{\prime \prime} \mathrm{N}, 103^{\circ} 45^{\prime} 46^{\prime \prime} \mathrm{E}$. The site was excavated in $10 \mathrm{~cm}$ spits with a sample of the excavated soil sieved using a $1 \mathrm{~cm}$ screen. The matrix was divided into layers based on soil colour. Four distinct layers were present at Prei Khmeng before archaeologically sterile soil was encountered.

\section{RESULTS}

Layer 1, at ca. $15.57 \mathrm{~m}$ a.s.1., contained 4035 ceramic sherds $(33.6 \mathrm{~kg})$, including ironand ash-glaze material of the Angkor period and a limited amount of earthenware. A line of 17 large laterite blocks was revealed in the northwest quadrant of the unit 
running to the southeast. In the northeast and southeast quadrants, bricks similar to those used in temple construction during the pre- and early Angkor periods were found.

Layer 2 was $40 \mathrm{~cm}$ in depth and contained domestic artifacts including ceramics $(12,825$ sherds, $103.2 \mathrm{~kg})$ and a whetstone, pestle, iron knife, slag cake, and agate bead.

The third layer was ca. $1 \mathrm{~m}$ deep. Some of the ceramics from the first spit $(3: 1)$ were identified as southern Chinese ceramics from the tenth and eleventh centuries and a lid fragment from a Kulen ceramic vessel dating to the tenth century (Naho Shimizu pers. comm. 2014). The third layer rendered considerable evidence for both domestic activity including ceramic sherds $(17,039$ sherds, $132.4 \mathrm{~kg})$ and metallurgy (iron bloom). Aligned post moulds filled with stones or brick fragments indicate that a large structure once stood in the location (Fig. 3). It is possible that the building was an elite residence or structure related to the temple as fine, glazed boxes, Chinese ceramics,

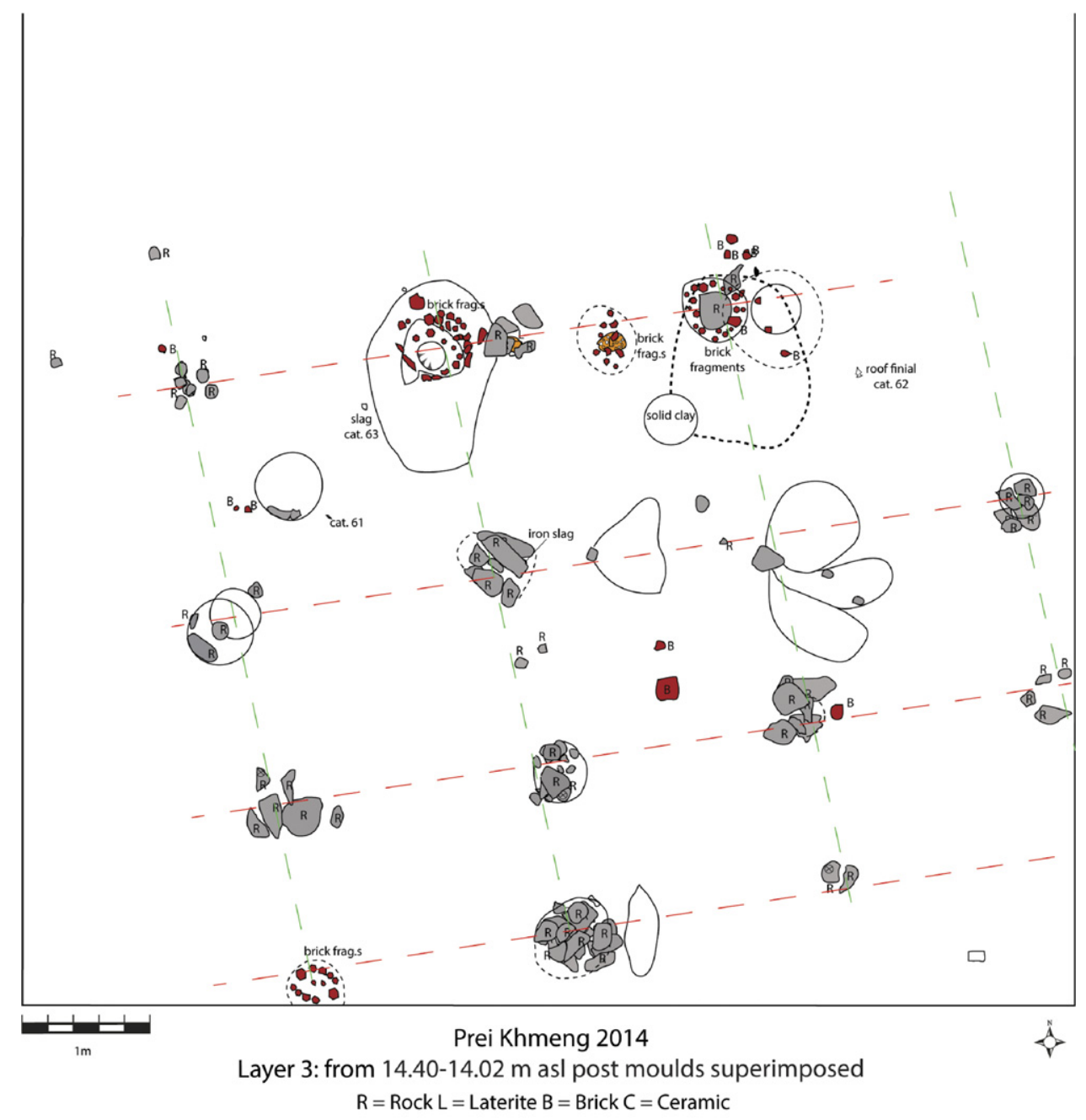

Fig. 3. Superimposed post-moulds in Layer 3 from 14.40 to $14.02 \mathrm{~m}$ a.s.1. at Prei Khmeng. 
many kendi spouts, glazed roof tiles, and an ornate roof finial were found in this context. Evidence of residential occupation in the immediate vicinity of religious foundations has been documented elsewhere in Angkor (Carter et al. 2018).

Layer 4 comprised 10 spits and totalled ca. $1 \mathrm{~m}$ in depth. This layer contained multiple post moulds (devoid of rocks or brick) and artifacts including earthenware ceramic sherds (8976 sherds, $68.3 \mathrm{~kg}$ ) and a spindle whorl, adze fragment, and sandstone pestle. In Layer 4, spit 5, mortuary contexts were discovered and post moulds continued in evidence, indicating a possible dual use of the area in question. The final spit in Layer 4 (spit 10) revealed fewer post moulds; these were dug into the undisturbed, basal sediments of the site. A sondage dug in the northeast quadrant confirmed that the matrix remained uniform and contained no further artifacts below ca. $13.30 \mathrm{~m}$ a.s.l.

\section{MORTUARY CONTEXTS}

The 11 mortuary contexts excavated during the 2014 field season contained the remains of adults and children and, where sex could be determined, included two possible females (one middle-aged and the other ca. 13-15 years old) and three or possibly four males (two of whom were middle-aged to older adults at death and two young adults) (Table 2). There was some variation in the way the dead were placed in the graves, with some arranged with the legs flexed and others supine, but neither position was restricted to males or females. All were discovered in the fourth layer of the excavation (see Fig. 2 inset for locations).

\section{Mortuary Context 1}

MC1 contained poorly preserved skeletal remains oriented with the head to the east. The skeleton, an adolescent between 13 and 15 years of age (based on the development of dentition) was supine (Fig. 4). A small globular vessel was placed to the south of the skull and a total of three bronze bangles were found on the arms. Glass beads were

Table 2. Mortuary Contexts Discovered at Prei Khmeng during 2014 Excavations

\begin{tabular}{lllllr}
\hline $\begin{array}{l}\text { MORTUARY } \\
\text { CONTEXT }\end{array}$ & \multicolumn{1}{c}{ AGE } & SEX & ORIENTATION & POSITION TYPE & $\begin{array}{c}\text { NUMBER OF } \\
\text { ARTIFACT TYPES }\end{array}$ \\
\hline 1 & 13-15 years & $?$ & East & Extended & 9 \\
2 & Mid-older adult & M & East & Extended & 33 \\
3 & 1.5 years & $?$ & West & Semi-flexed & 12 \\
4 & Mid-older adult & M? & West & Semi-flexed & 7 \\
5 & Middle-aged adult & F? & East & Semi-flexed & 25 \\
6 & Young adult & M & East & Semi-flexed & 24 \\
7 & Neonate & $?$ & East & & 12 \\
$4: 6$ F2 & $?$ & $?$ & $?$ & & 13 \\
8 & 0.5 years & $?$ & & & 16 \\
9 & Young adult & M & East & Semi-flexed & 32 \\
10 & Young adult & F? & Northeast & Extended & 53 \\
\hline
\end{tabular}




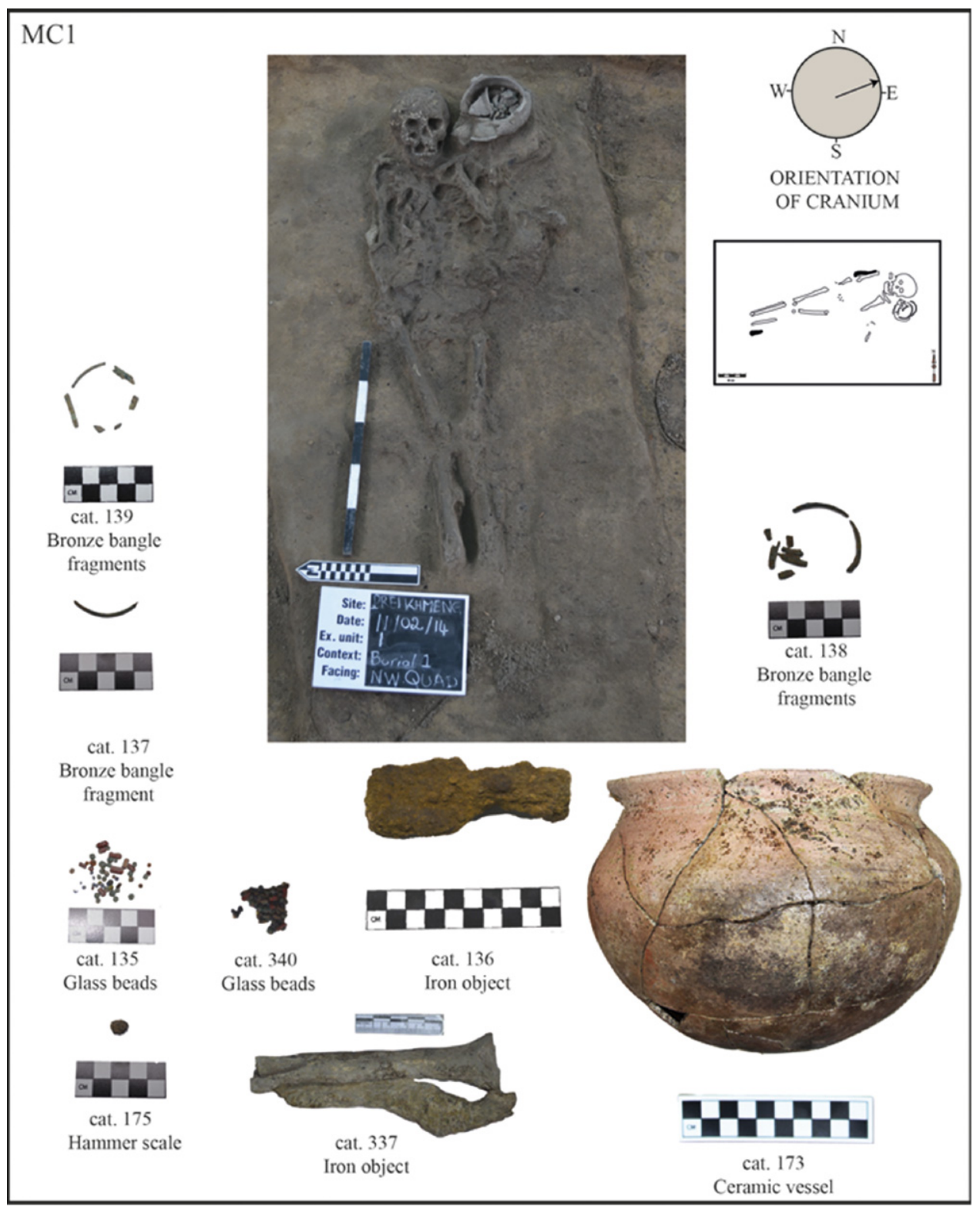

Fig. 4. Mortuary Context 1 with grave goods.

scattered in the thoracic and pelvic regions and more around the mandible. Iron tools were placed at the left ankle and right humerus. This young individual showed no signs of dental pathology, but the absence of the left lateral maxillary incisor may represent antemortem dental modification. This is evident in other individuals at this site and is common in this region though not usually in one so young during this time period (Domett et al. 2013; Newton and Domett 2017). 


\section{Mortuary Context 2}

This interment contained a middle-aged to older male (based on pelvic and cranial morphology) placed in a supine position with the legs and arms extended and the head oriented to the east (Fig. 5). Three ceramic vessels were found in the grave, including a globular vessel at the right shoulder, a bowl on the chest, and a large vessel by the left arm. Other artifacts include glass beads, a tubular agate bead, a clay pellet, iron implements identified as digging tools, spears, a sickle and two axes, two bronze bangles, and eleven bronze bells. The individual was also buried with a juvenile pig skull. This man stood approximately $162.9 \mathrm{~cm}$ tall, which is just slightly shorter than the average for males in the region (Domett and O'Reilly 2009; Sangvichien et al. 1985). He suffered from extensive periodontal disease and a number of teeth (including the right mandibular central and lateral incisors) had been lost from disease or possibly removed antemortem.

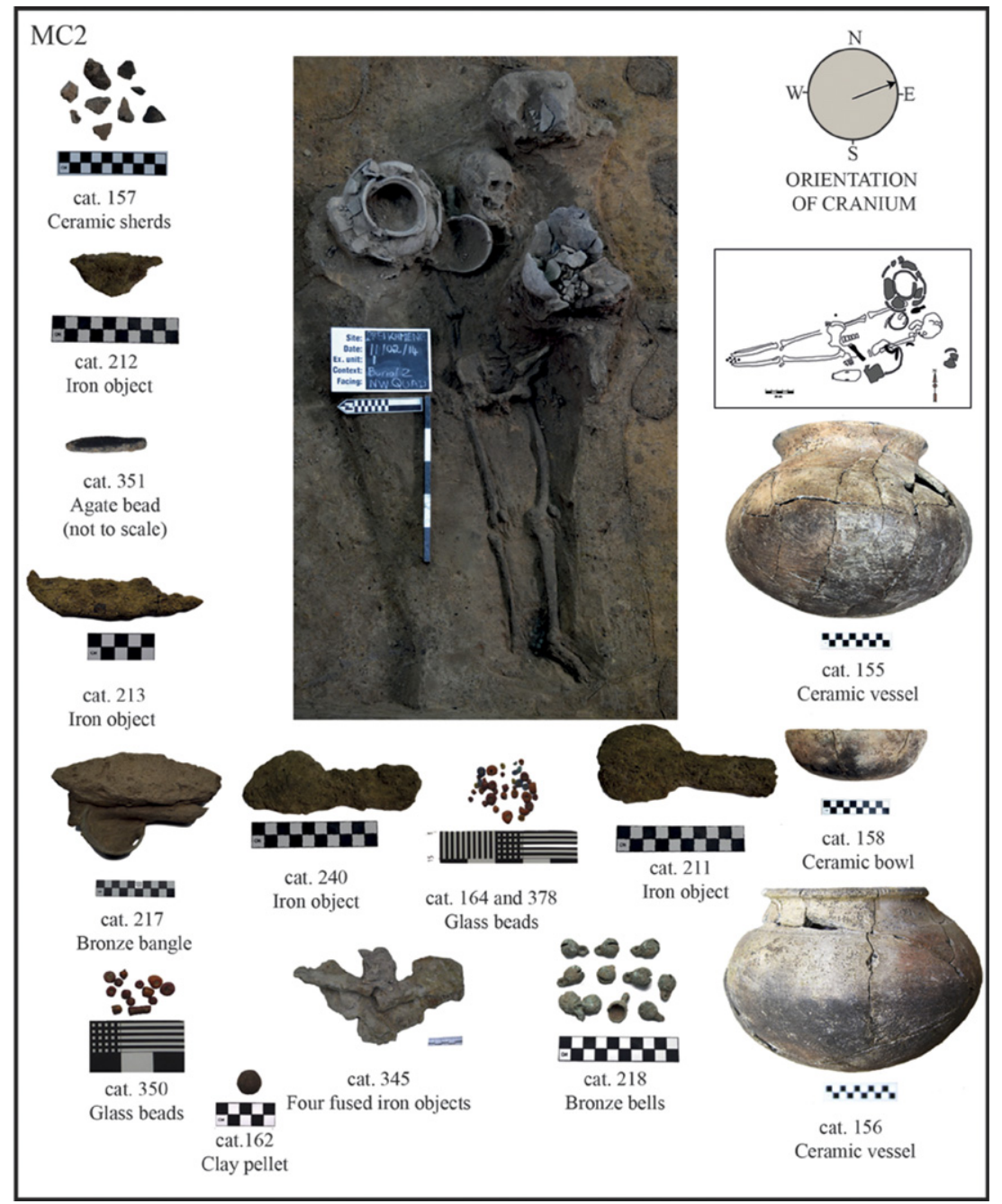

Fig. 5. Mortuary Context 2 with grave goods. 


\section{Mortuary Context 3}

This grave contained the remains of a poorly preserved infant, ca. 1.5 years old (based on the femoral diaphysis length and dental development), buried with flexed legs. Similar positioning was noted during the MAFKATA excavations and interpreted by the excavator as the result of taphonomic factors (Pottier 2001). The artifacts comprised iron tools, eight tubular agate beads, a bronze earring, a collection of glass beads found around the cervical vertebrae, and a bronze bangle on the left humerus (Fig. 6).

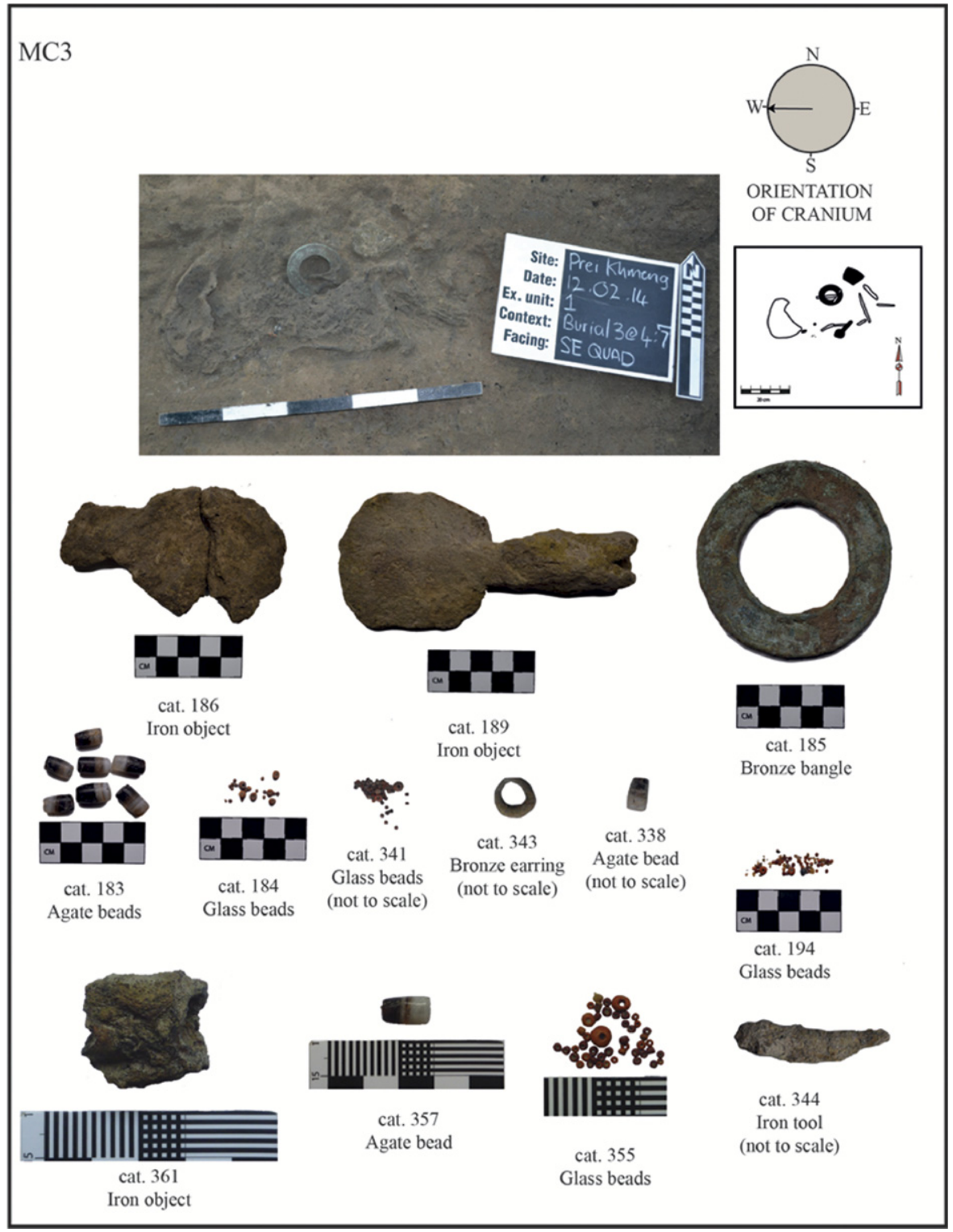

Fig. 6. Mortuary Context 3 with grave goods. 


\section{Mortuary Context 4}

MC4 comprised the remains of a middle-aged to older adult, possibly male (based on pelvic and cranial morphology and severe dental attrition), buried with his hands resting in the pelvic region, legs flexed, and the skull oriented to the west (Fig. 7). Artifacts associated with the burial include a bronze earring on the left side of the skull, a ceramic vessel at the feet, three bronze bangles on the left forearm and an iron tool near the skull. This man is estimated to be $161.3 \mathrm{~cm}$ tall based only on the length of the right radius. Of particular note is his possibly edentulous maxilla and the advanced attrition in the mandibular dentition, which also exhibits heavy calculus (plaque) deposits and periapical cavities indicative of infection of the gums and the surrounding alveolar bone.

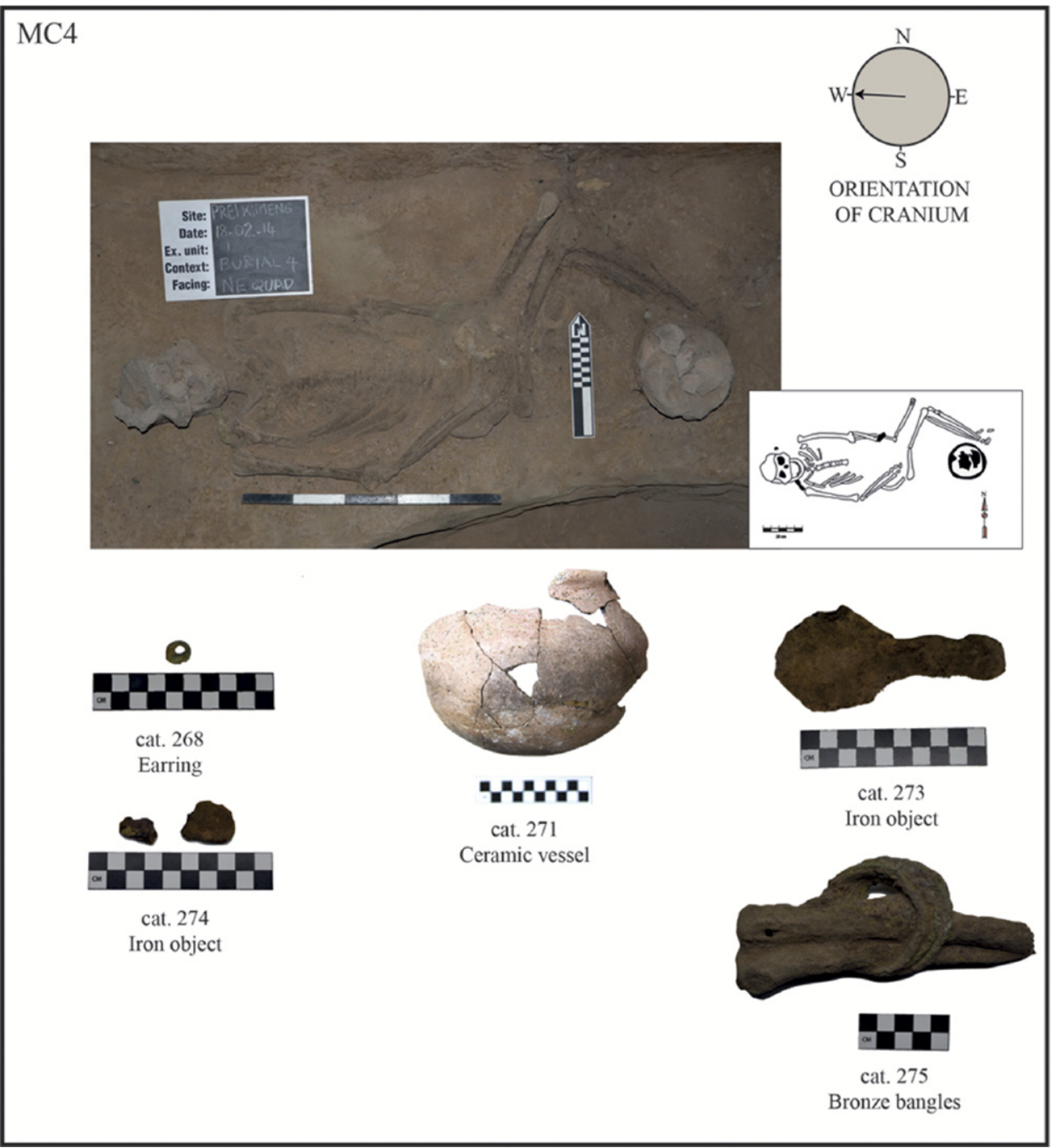

Fig. 7. Mortuary Context 4 with grave goods. 


\section{Mortuary Context 5}

This interment contained a middle-aged possible female (based primarily on cranial morphology and dental wear) buried supine with flexed legs and the arms folded on the thorax (Fig. 8). Glass beads, three bronze finger rings, and an iron projectile point were placed on the chest. Other items in the grave included a pig's mandible, three ceramic vessels (two of which were nested), a carnelian bead, ten bronze bangles, and two clay pellets. While the skeletal remains were poorly preserved, there was evidence for the intentional antemortem removal of both maxillary lateral incisors.

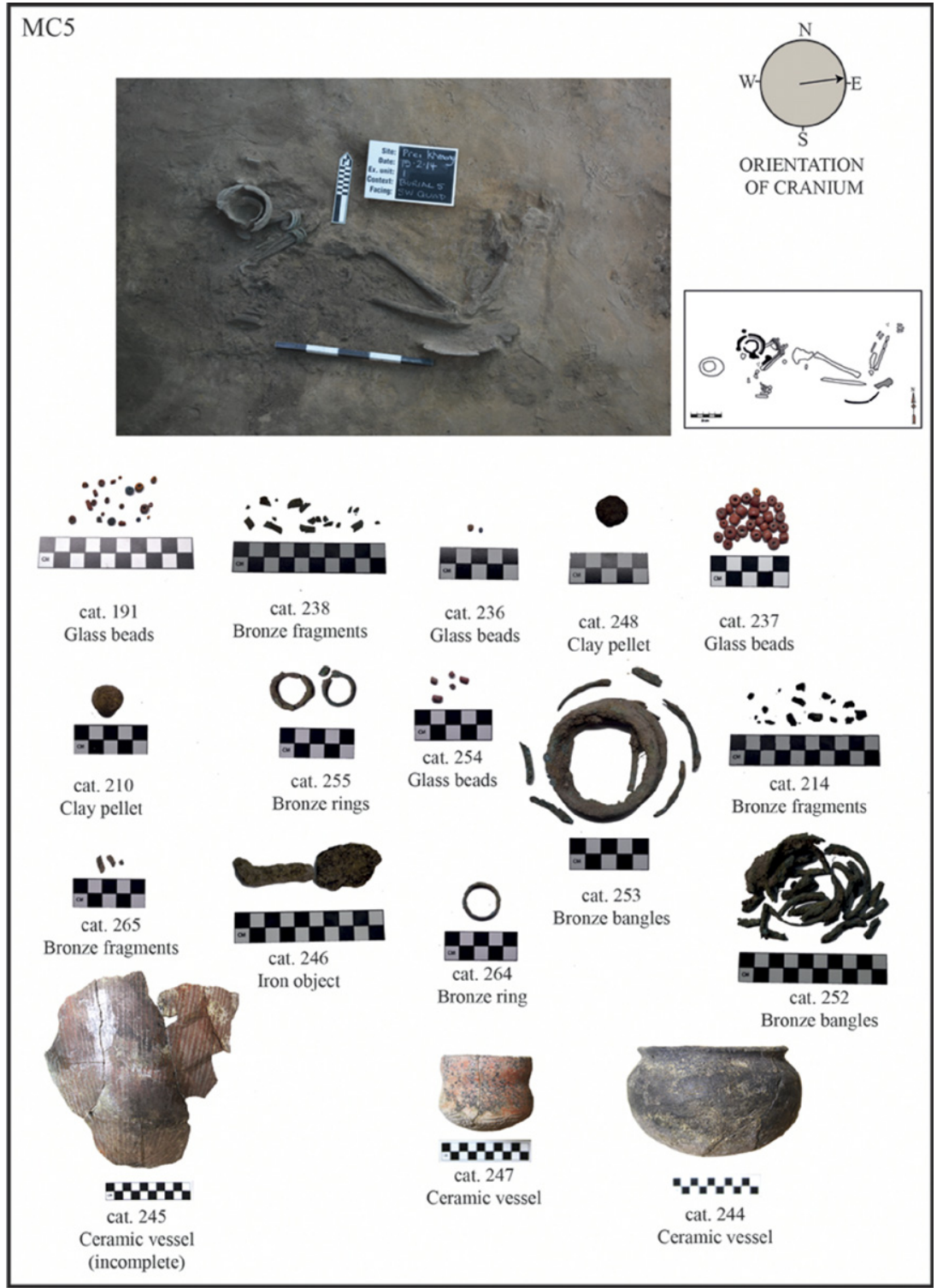

Fig. 8. Mortuary Context 5 with grave goods. 


\section{Mortuary Context 6}

A young adult male (based on late-fusing epiphyses and pelvic and cranial morphology) was found supine with the legs flexed and hands crossed over the abdomen (Fig. 9). The skull was oriented to the east. Two ceramic vessels (and sherds), five bronze bangles

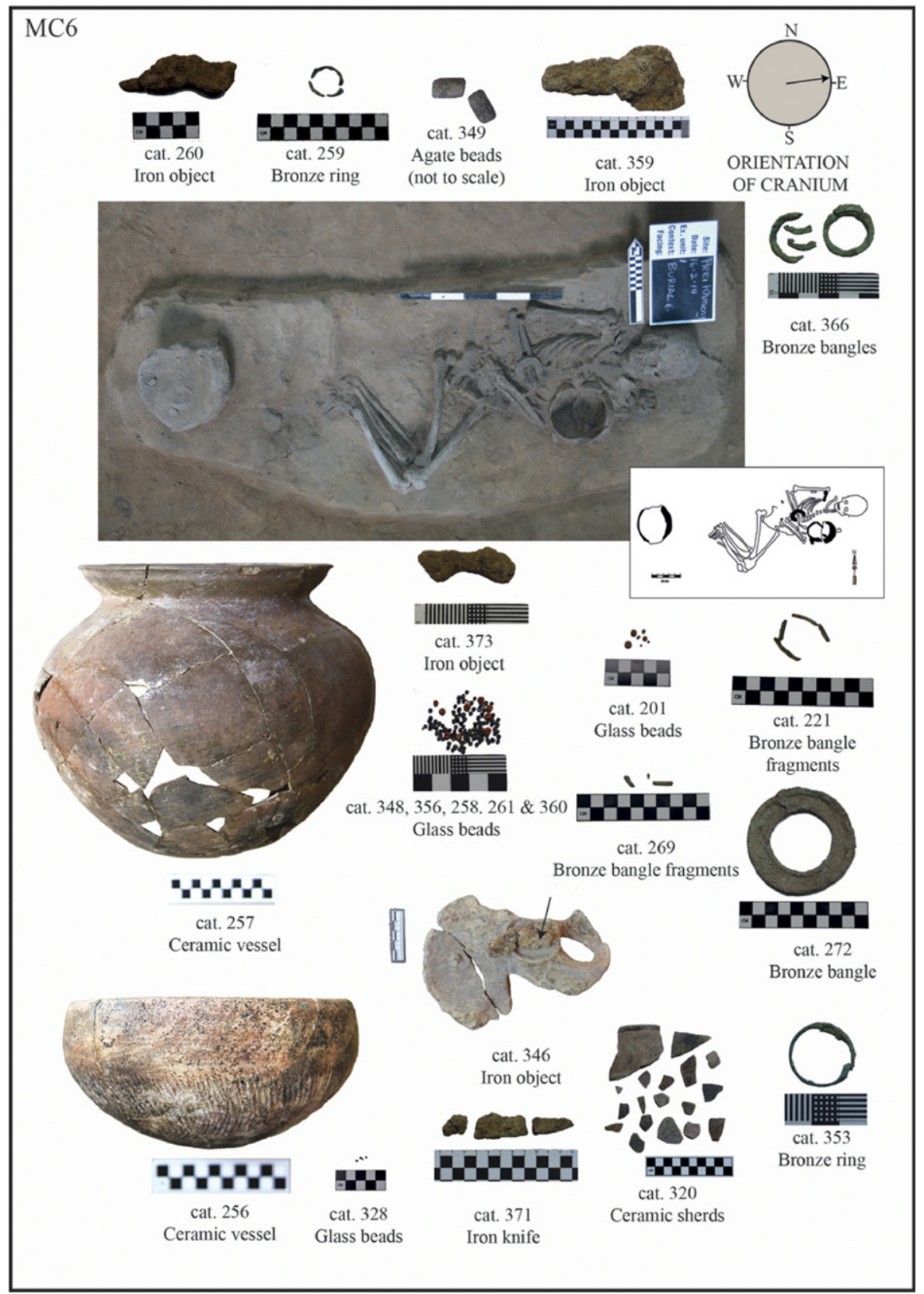

Fig. 9. Mortuary Context 6 with grave goods. 
Table 3. Radiocarbon Dating Results from Excavations at Prei Khmeng in 20 i 4

\begin{tabular}{llrrr}
\hline S-ANU\# & \multicolumn{1}{c}{ PROVENANCE } & ${ }^{14}$ C AGE & CALIBRATED A.D. & PROBABILITY (\%) \\
\hline 38821 & $3: 9$ NW Quad & $1605 \pm 25$ & $399-536$ & 95.4 \\
38623 & MC1 & $1780 \pm 25$ & $140-333$ & 95.4 \\
38625 & MC1 & $1910 \pm 25$ & $23-138$ & 95.4 \\
38626 & MC1 & $1820 \pm 25$ & $127-311$ & 95.4 \\
38624 & MC1 & $1855 \pm 25$ & $85-230$ & 95.4 \\
38620 & MC2 & $1695 \pm 25$ & $257-406$ & 95.4 \\
38621 & MC2 & $1855 \pm 25$ & $85-230$ & 95.4 \\
38619 & MC4 & $1765 \pm 30$ & $142-379$ & 95.5 \\
38618 & MC6 & $1720 \pm 25$ & $251-389$ & 95.4 \\
38617 & MC7 & $1770 \pm 30$ & $138-345$ & 95.4 \\
38815 & MC7 & $1565 \pm 20$ & $425-545$ & 95.4 \\
38816 & MC7 & $1720 \pm 25$ & $251-389$ & 95.4 \\
38817 & MC7 & $1660 \pm 30$ & $260-529$ & 95.5 \\
38627 & MC10 & $1780 \pm 25$ & $140-333$ & 95.4 \\
38825 & $3: 1$ NW Quad & $1080 \pm 25$ & $895-1018$ & 95.4 \\
38823 & 3:2 F9 NW Quad & $1580 \pm 30$ & $410-546$ & 95.4 \\
38819 & $4: 1$ NW Quad & $1865 \pm 25$ & $80-223$ & 95.4 \\
38820 & $3: 3$ SE Quad & $1025 \pm 30$ & $903-1146$ & 95.4 \\
38824 & $3: 7$ SE Quad & $1500 \pm 35$ & $430-642$ & 95.4 \\
38818 & $4: 2$ bottom of F62 SW Quad & $1560 \pm 60$ & $385-623$ & 95.4 \\
\hline
\end{tabular}

and bronze rings, iron tools, and glass and agate beads were found around the skeleton. Charcoal from this context was dated (Table 3). MC6 is one of two excavated burials furnishing evidence of perimortem trauma (the other is MC10, described below). One unhealed lesion on the iliac fossa (pelvis) is suggestive of penetration by a sharp point, while a further unhealed depression fracture on the pubic bone (anterior pelvis) suggests blunt force trauma. This young man was also differentiated by his very short stature. He was estimated to be only ca. $150 \mathrm{~cm}$ tall (Feldesman and Fountain 1996; Sangvichien et al. 1985; Sjøvold 1990).

\section{Mortuary Context 7}

MC7, a neonate (based on bone size), was located directly to the north of another mortuary context labelled 4:6 Feature 2 (described below) (Fig. 10). These two grave cuts seem to be conjoined and are likely contemporaneous. The human bone was very poorly preserved, comprising only cranial, rib, and radius fragments. Two ceramic vessels associated with the interment were more than $20 \mathrm{~cm}$ to the south, suggesting perhaps that other perishable items may have once filled the void. The other artifacts in the burial include a bronze bangle on the right arm and a fragment of bronze located near a juvenile pig's cranium located in the southwest corner of the grave cut. Two iron 


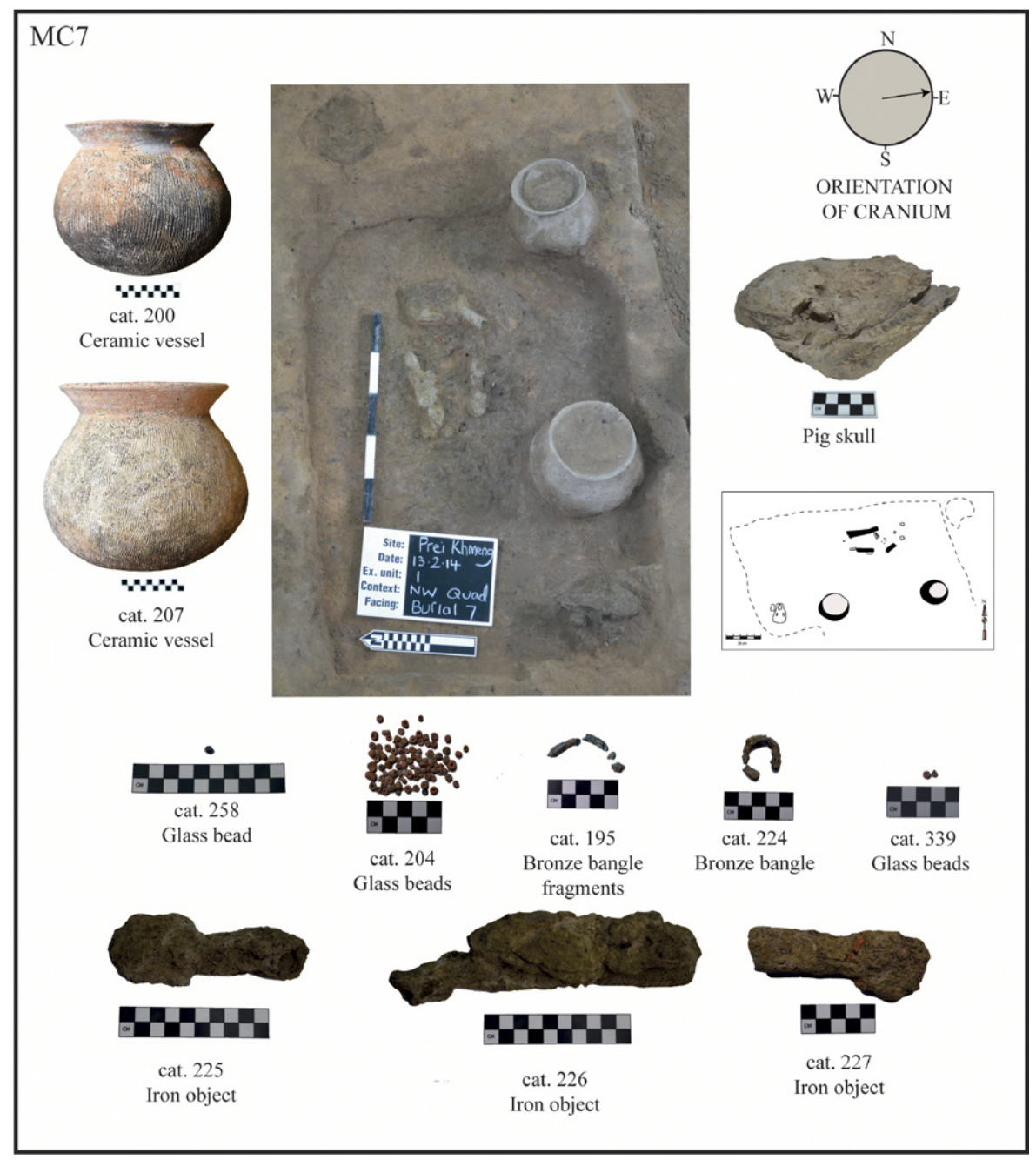

Fig. 10. Mortuary Context 7 with grave goods.

tools and a slightly curved knife or sickle were also found in the context. Glass beads were found in the thoracic area and near the skull. Charcoal from this context was dated (Table 3).

\section{Mortuary Context (4:6 Feature 2)}

Directly south of MC7, a grave cut (4:6 Feature 2) was discerned that contained three ceramic vessels (a bowl and two globular pots), a pig skull, a clay pellet, bronze bangle fragments, a tubular agate bead and agate bead fragments, two carnelian beads (one tubular and the other barrel-shaped), a glass bead, and iron tools (Fig. 11). No human remains were encountered, probably due to taphonomic factors that led to the dissolution of the bone. 


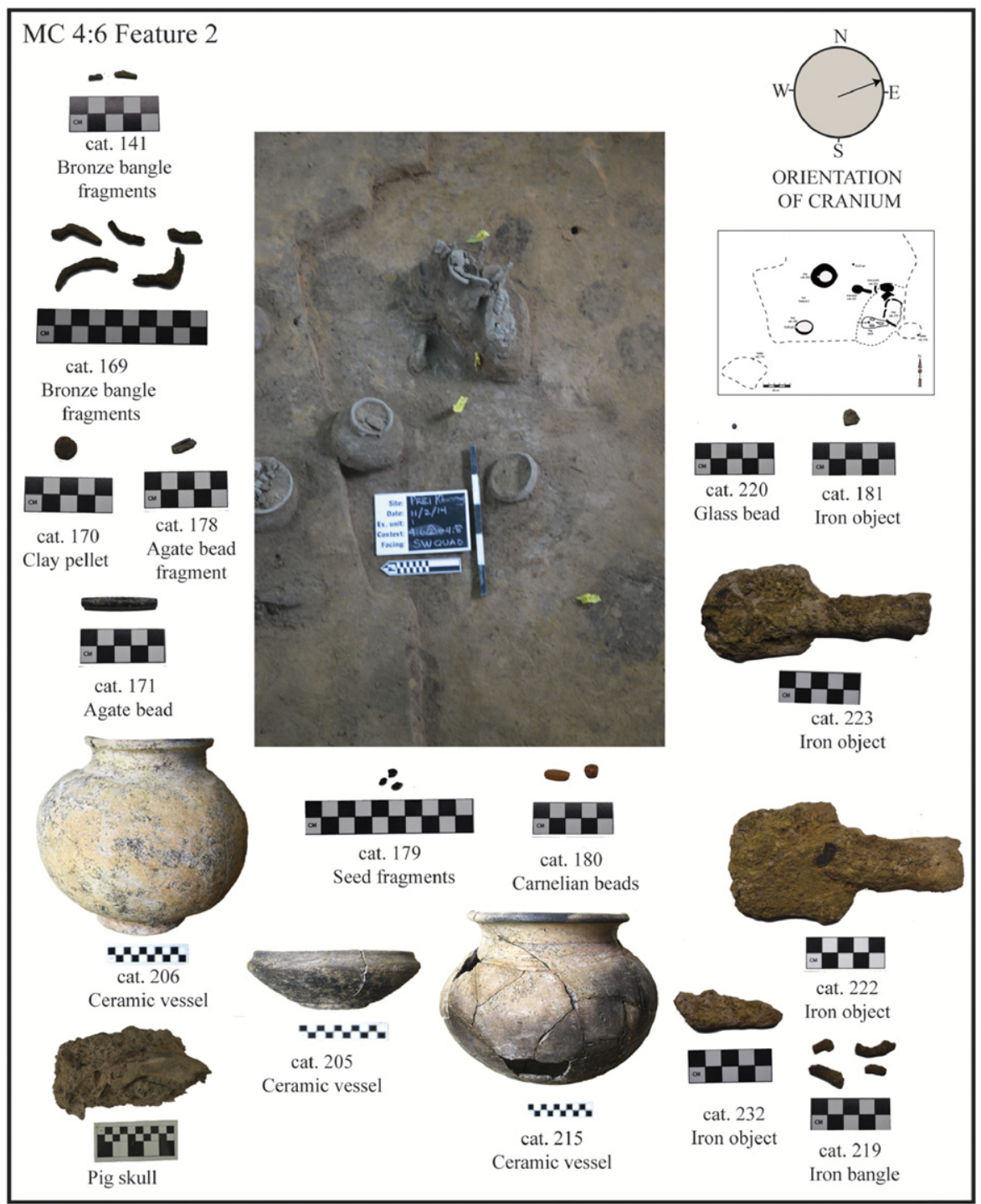

Fig. 11. Mortuary Context (4:6 Feature 2) with grave goods.

\section{Mortuary Context 8}

Minimal skeletal material of a 6-month old child (based on the development of one deciduous molar) remained in MC8 (Fig. 12). A number of artifacts were discovered, including a ceramic vessel, two bronze rings, three iron tools, and a few glass beads. The burial also contained what may be nine small bronze coins (ca. $9 \mathrm{~mm}$ diam.). It is possible that these are in fact bronze "beads" resembling coins. The artifacts and skeletal remains sat atop a bed of rice remains. 


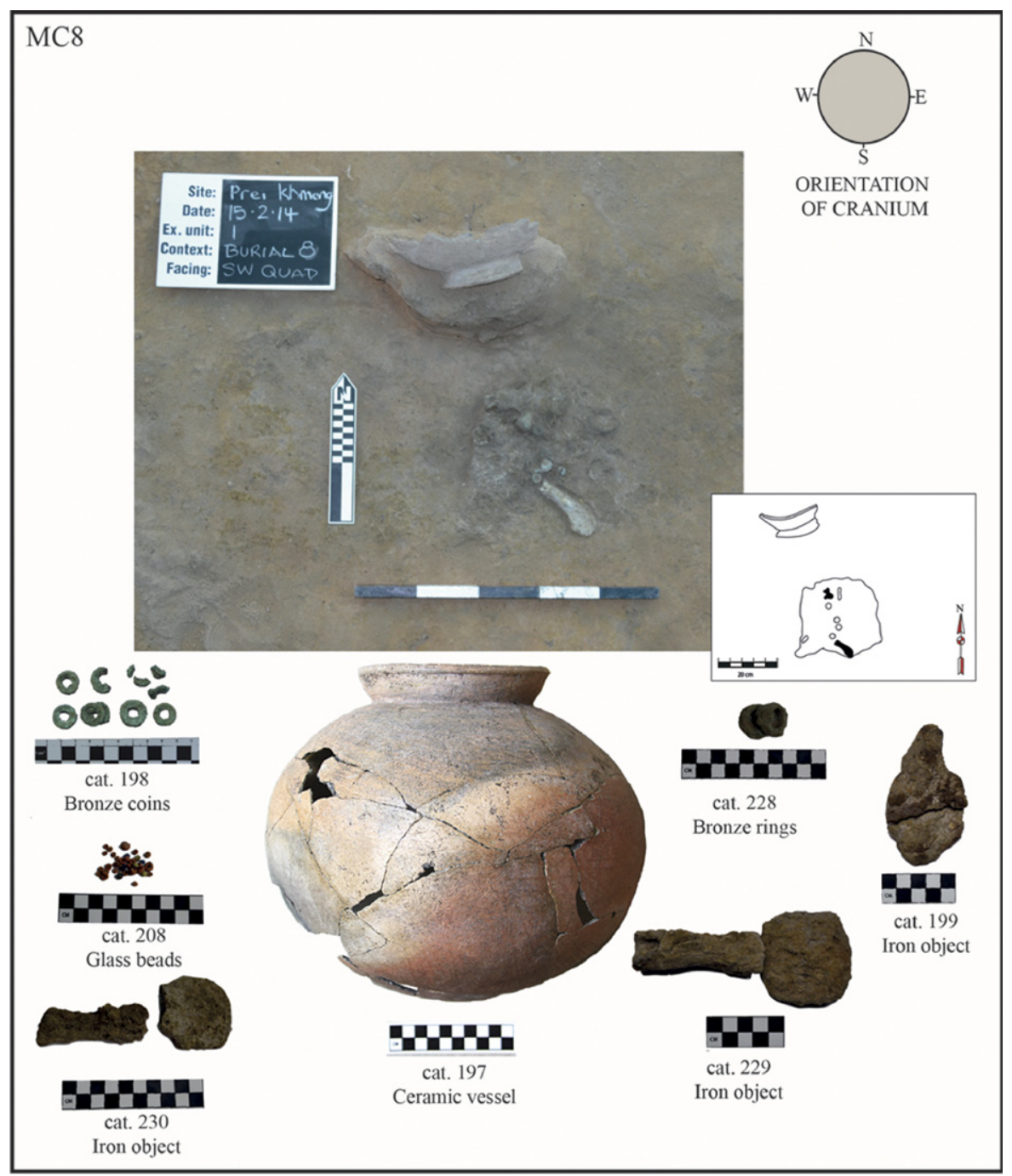

Fig. 12. Mortuary Context 8 with grave goods.

\section{Mortuary Context 9}

A poorly preserved skeleton of a young adult male (based on pelvic morphology including the pubic symphysis) was uncovered buried with his arms alongside the body and hands over the abdomen. The legs were flexed and the head oriented west-southwest (Fig. 13). The skeleton was accompanied by three complete ceramic vessels, sherds, two tubular agate beads, several iron tools, and a bronze bangle on the left forearm and three bronze bangles on the right forearm. One hand bore five bronze rings, with some glass beads in the same vicinity. Stature was estimated to be $164.2 \mathrm{~cm}$. The dentition shows a number of periapical lesions indicative of infection around the gum and alveolar bone in the posterior teeth of the mandible and maxilla. In addition, one left maxillary central incisor is missing; the remodelled alveolar bone suggests this tooth was lost antemortem, though it could not be determined if this was the result of pathology or intentional ablation. 


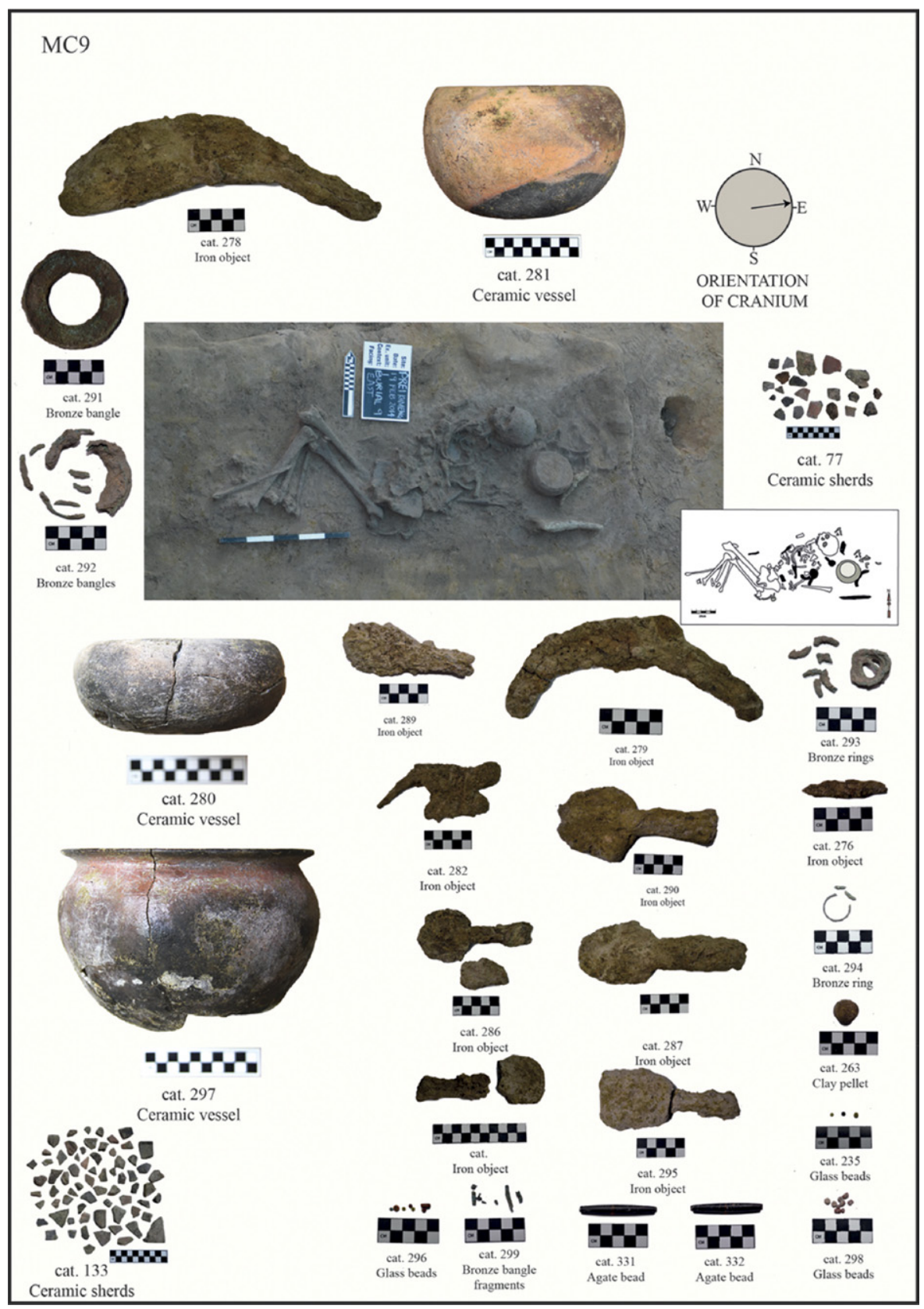

Fig. 13. Mortuary Context 9 with grave goods. 


\section{Mortuary Context 10}

MC10, a young adult, possibly female (18-25 years old based on cranial morphology, late fusing epiphyses, and erupting third molars), was placed in a supine position with the legs and arms straight, hands by the sides, and the skull to the east-northeast (Fig. 14). The burial was the wealthiest of those excavated and included a large,

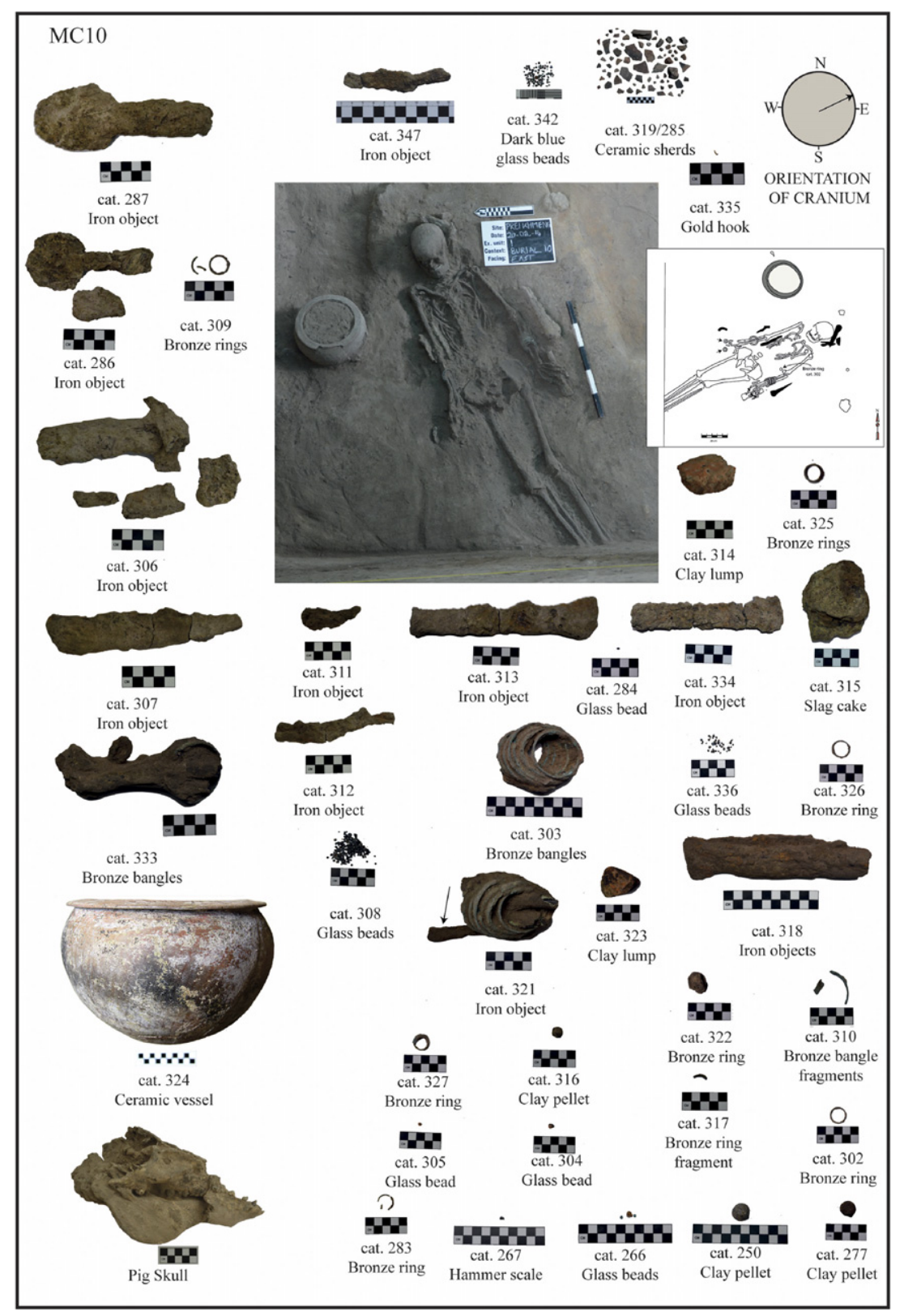

Fig. 14. Mortuary Context 10 with grave goods. 
globular ceramic vessel in which a juvenile pig's mandible had been placed. The burial also contained ceramic sherds, a lump of burned clay, and over 14 iron implements comprising tools and projectile points. Of note was the placement of one of these tools in the left hand of the individual. Other items in the interment include 95 glass beads, a small gold hook, three clay pellets, fish bone, and ten bronze bangles. Some possible hammer scale from smithing activity was found in the grave fill and a slag cake to the south of the skull (ca. $50 \mathrm{~cm}$ away). A piece of charcoal recovered from the burial was dated (Table 3). This young woman was $153 \mathrm{~cm}$ tall, close to the average for some other Iron and Bronze Age sites in mainland Southeast Asia (Domett and O'Reilly 2009). Her dentition showed light wear with no sign of pathology or intentional tooth removal. Of particular interest is the presence of two perimortem lesions which penetrate the internal and external aspects of the ilium (pelvis) congruent with damage caused by a sharp implement. These were very similar to the lesion of the ilium in MC6, with both individuals also being buried with iron implements underlying the pelvis. Because of the poor preservation of the iron implements, it is difficult to determine if they were used to inflict the wounds.

\section{RADIOCARBON DETERMINATIONS}

Nineteen charcoal samples were collected during the excavation of Prei Khmeng for radiocarbon dating. The majority of these were from mortuary contexts including MC1 $(n=4), \operatorname{MC} 2(n=2), \operatorname{MC} 4(n=1), \operatorname{MC} 6(n=1), \operatorname{MC} 7(n=4)$, and MC10 $(n=1)$ (Fig. 15). These dates should be considered in light of ongoing concern as to whether charcoal from burial contexts can be used directly to infer the date of the interred skeletal material (Higham 1994; Higham T. et al. 2009). The remaining samples were collected from level spits or features.

Mortuary contexts with more than one carbon sample were pooled in Figure 15, indicating that the burials all date to roughly the same period, A.D. 200-400. ${ }^{2}$ Chronologically, the burials at Prei Khmeng are also contemporaneous to those dating to what Higham (2011) terms "Iron Age 3," ca.A.D. 200-400.

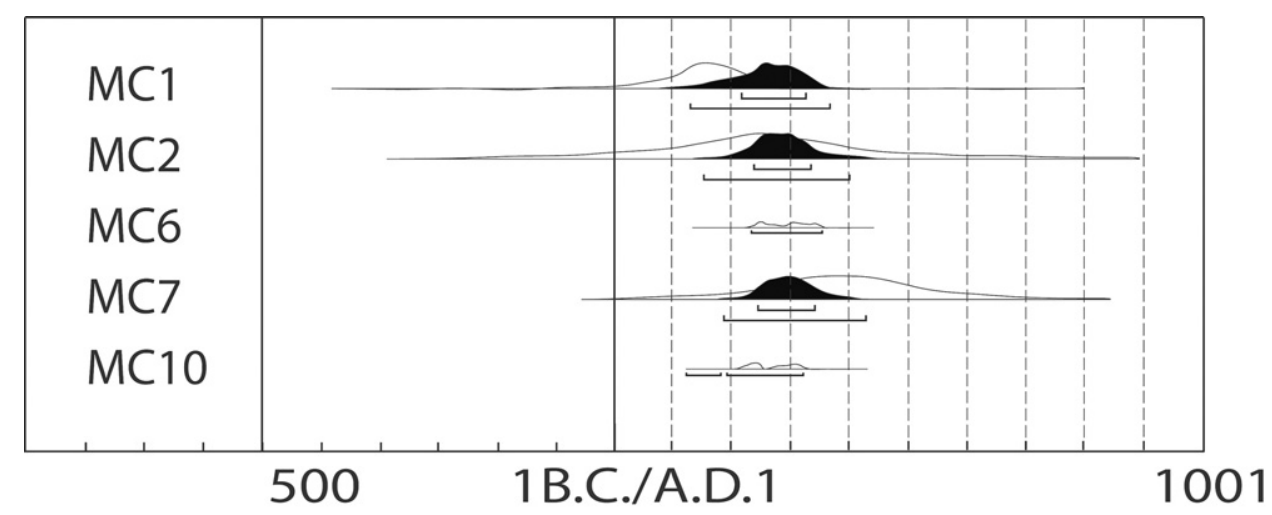

Fig. 15. Radiocarbon probability distributions from Prei Khmeng 2014 excavations; mortuary contexts listed in left column (data summarized following Ramsey 2017). 


\section{DISCUSSION}

The Iron Age in Southeast Asia is considered a transformative period characterized by emerging socio-political complexity. Indicators of this development include evidence for intensified agricultural production, burgeoning regional trade and exchange, specialist ceramic production, developments in site morphology, and rising social conflict (Carter 2013; Domett et al. 2011; Higham 2007, 2011, 2012a, 2014; Higham and Kijngam 2012; O'Reilly 2000, 2008, 2014; O'Reilly and Shewan 2016a, 2016b). Hallmarks of increasing complexity can be found at Prei Khmeng and other contemporaneously occupied sites in Cambodia excavated by the authors, including Lovea in the Angkorian heartland, Sophy and Snay in Northwest Cambodia, and Iron Age (ca. A.D. 200-600) sites in Northeast Thailand (Higham 2012b; Higham et al. 2014; Higham and Kijngam 2012).

\section{Prei Khmeng Mortuary Contexts}

The eleven mortuary contexts excavated during the 2014 field season contained a population of young and old, male and female individuals as detailed above. The accompanying mortuary assemblage at Prei Khmeng comprised items such as iron tools, glass and stone beads, bronze jewellery, ceramic vessels, and faunal offerings which mirror the material culture assemblage recovered during the MAFKATA excavations. The French/Khmer team also reported bronze ear coils being found near the skull of one of the interred individuals, an iron plate under the skull of a child (Pottier, Bolle et al. 2009), and fine-paste, high-fired ceramic vessels decorated with red and black paint (so dubbed "rouge et noir [red and black]" ceramics) which are estimated to date to the mid- to late Iron Age (Lim pers. comm. 2018).

The 2014 Prei Khmeng excavations revealed some variation in grave wealth, with five individuals being interred with a greater number and more varied items than others, but overall the interments were poorly furnished in terms of accompanying grave goods. There does not appear to be any correlation between the quantity of grave goods or the orientation or positioning of the skeleton. The richest interment was a young adult (possible female) with 53 artifacts (MC10). Mortuary contexts 2, 5, 6, and 9 had similar numbers of artifacts, with between 24 and 33 in each. The remaining burials were interred with between nine and 16 objects. The poorest burial, MC4, a middle to old-aged adult male, was interred with only seven items. A similar situation is evident in the MAFKATA excavated burials, where most individuals were interred with between one and seven items (Pottier, Baty et al. 2003; Pottier, Guerin et al. 2001a; Pottier, Guerin et al. 2001b); however, one individual in this population was buried with ca. 1700 glass beads (Pottier, Baty et al. 2003).

\section{Dental Modification and Trauma}

One individual among the 2014 Prei Khmeng burial sample revealed evidence for tooth ablation. The possible female in MC5 was missing both maxillary incisors; this symmetrical loss is suggestive of intentional removal of the teeth. Anterior teeth may have been removed intentionally from a number of other individuals, but the incompleteness of the maxillae and mandibles precludes a confident interpretation. Pottier, Bolle, and colleagues (2006) also record the practice of tooth ablation at Prei 
Khmeng. The ante-mortem removal of teeth has been noted elsewhere in Cambodia, with 60.2 percent of individuals excavated at Iron Age Snay and 47.8 percent of the sample from Sophy demonstrating anterior maxillary dental ablation (usually the lateral incisors) and other cases include the mandible (Domett et al. 2013). Ablation was also evident in three individuals buried at Bronze Age Koh Ta Meas, $3 \mathrm{~km}$ from Prei Khmeng, where both canines and lateral incisors were removed from the maxilla (Frelat and Souday 2015; Frelat et al. 2016; Pottier, Llopis et al. 2006). This common occurrence in Iron Age Cambodia is noteworthy as it is rare in neighbouring Northeast Thailand contexts.

Two individuals found during the 2014 Prei Khmeng excavation, a male (MC6) and a possible female (MC10), demonstrated evidence of perimortem trauma likely inflicted with a sharp instrument. A forthcoming article will discuss the details of this and other aspects of health and disease in the Prei Khmeng community. Evidence for conflict/trauma can also be found at Snay, where a significant amount of weaponry is recorded in the burial assemblage and a high number of injuries, especially to the head, has been documented. A total of 30 individuals (23.4\% of the investigated sample) from Snay demonstrated evidence of either sharp or blunt force cranial trauma suggesting that the pre-Angkorian period was one of instability.

\section{Site Morphology and Use Duration}

Excavations indicate that the area of the prehistoric cemetery at Prei Khmeng continued to be occupied after the abandonment of the cemetery. The location of the temple at Prei Khmeng, which was erected in the sixth or possibly early seventh century A.D. (Pottier 2012), and the cemetery upon which it is built is of interest. ${ }^{3}$ The temple is not the only structure in the immediate area, as domestic refuse and evidence of a structure in the form of aligned, rock-filled post moulds was uncovered in the 2014 excavations. Ceramic tiles and a roof finial found in the matrix may indicate that the structure located here was either occupied by an individual or family of high rank or was a religious structure, since the use of roof tiles, at least in the thirteenth century A.D., was restricted to wealthy houses or sacred structures (Zhou 2007:50). The K.774 inscription found at Prei Khmeng does not provide specific information on the preAngkorian temple at the site, but mentions a date corresponding to A.D. 989. The K.774 inscription does mention the date of completion of the Bakheng temple during the reign of Yasovarman (prior to A.D. 895) and donations made ca. A.D. 860 which Pottier and colleagues (2001) suggest indicates use of the sanctuary at Prei Khmeng at least until the end of the tenth century A.D. As has been noted above, some of the ceramics found in the third layer at Prei Khmeng date from the tenth and eleventh centuries. This layer returned radiocarbon dates spanning the period 895-1146 cal. A.D. The use of the site after the twelfth century is not firmly established but it was certainly (re-)occupied by the nineteenth century (de Lajonquière 1911).

\section{Prei Khmeng in a Regional Context}

Located $8 \mathrm{~km}$ to the northwest of Prei Khmeng, we recovered 12 interments at the site of Lovea (ca. 100-300 A.D.) (O'Reilly and Shewan 2015a, 2016a). The burials contained similar grave goods to those found at Prei Khmeng, including most notably nearly identical large biconical carnelian beads and possible Chinese coins. In 
northwest Cambodia, Phum Snay (ca. 200 B.C.-A.D. 200), about $64 \mathrm{~km}$ northwest of Prei Khmeng (O'Reilly et al. 2006), and Phum Sophy (ca. A.D. 1-500), a further $40 \mathrm{~km}$ northwest in Banteay Meanchey Province (O'Reilly and Shewan 2015b), revealed similar mortuary traditions (see review in O'Reilly and Shewan 2016b).

While the size of the mortuary assemblage recovered from Prei Khmeng precludes statistical analysis and is dwarfed by those recovered at Iron Age sites in Northeast Thailand, it demonstrates broad similarities in material culture to Northeastern Thai sites of a similar age. In Northeast Thailand, the dead are frequently interred with ceramics, bronze ornaments, iron implements, and glass, agate, and carnelian beads (Higham 2012b). There are notable differences, too, as Prei Khmeng has no evidence for bimetallic (bronze/iron), gold, or silver rings, nor do we find evidence for clay-lined grave cuts similar to those found in Northeast Thailand. The nucleation of burials, a hallmark of early Iron Age mortuary contexts in Thailand, is also absent.

The material culture assemblage found at Prei Khmeng and other contemporary Cambodian and Thai Iron Age sites mentioned in the text provide evidence for expanding regional exchange and interaction networks. Exotic artifacts recovered from the mortuary contexts from these sites include agate, carnelian, and glass beads, specially crafted ceramics, jewellery, and possibly coinage. Stone and glass beads, argued to be of South Asian origin, are common in burial assemblages in Iron Age sites in Cambodia and Thailand (Bellina 2003; Carter 2010, 2013; Latinis 2004). Carter's (2015a) analysis of the stone and glass beads from Prei Khmeng (from both the MAFKATA and more recent excavations) indicate that these objects likely have a similar origin. The glass beads were found to have a high alumina mineral soda content, a trait that is strongly associated with manufacture in Sri Lanka, while the stone beads were found to be geochemically analogous to northwestern Indian stone sources and were likely imported from this region (Carter 2015a, 2015b).

Although it is likely that the bulk of the ceramic recovered at Prei Khmeng was locally produced, it is conceivable that a majority of the low and high-fired fine-paste earthenware ceramics recovered there may have been traded and exchanged from either production or redistribution (market) centres outside the site (Lim pers. comm. 2018). Ceramic resembling the distinctive Northeast Thailand, burnished Phimai black ware (ca. A.D. 200-400) were discovered during the MAFKATA excavations at Prei Khmeng though not in the 2014 excavations (Pottier, Guerin et al. 2001a:52).

Further evidence for regional interaction may be indicated by the presence of Chinese coins. A single coin (ca. $34 \mathrm{~mm}$ diam.), tentatively identified as dating to the Wang Mang interregnum (A.D. 7-23), was discovered in a mortuary context at Lovea (O'Reilly and Shewan 2016a). While smaller than the Lovea coin, nine possible coins (ca. 9-11 mm diam.) were recovered from MC8 at Prei Khmeng. Neither the coins from Lovea nor Prei Khmeng have inscriptions. Examples of small Chinese coins such as those at Prei Khmeng are unusual, although similar sized examples are known from Qiuci (龟兹) a kingdom centered on the present-day city of Kucha in Xinjiang. Some of the Qiuci bronze coins bear no inscription and were produced from A.D. 265 to 589 (Ashkenazy 2018; Klimeš 2004). Whether these are indeed coins remains to be ascertained through further analysis.

The practice of filling a mortuary context with rice or rice byproduct, as was noted at Prei Khmeng in MC8, is also known in Northeast Thailand, having been found in 
Iron Age contexts at Non Muang Kao, Noen U-Loke, and Non Ban Jak (Higham 2012b, 2014; O’Reilly 2007; Talbot 2007).

The position of some of the skeletons also merits mention. Many of the interments were found to have their legs in a flexed position; a practice also noted at Snay, Sophy, and other sites of the same age in Cambodia including Krosaing Thmei (Sok 2006) and Kok Treas (Heng et al. 2013).

The placement of pig (Sus scrofa) remains in burials as found in Prei Khmeng has also been documented in sites throughout the region (Pottier, Baty et al. 2003; Pottier, Bolle et al. 2006; Pottier, Guerin et al. 2001b). These include the Bronze Age site of Koh Ta Meas (Frelat and Souday 2015), Iron Age Angkor Borei in Takeo Province (Ikehara-Quebral et al. 2017; Stark 2001), and Prohear in southern Cambodia (Reinecke et al. 2009). The practice is also known in Northeast Thailand from the Neolithic period at Ban Non Wat (Higham and Thosarat 2006) and Iron Age sites such as Noen U-Loke (Higham 2011) and Non Ban Jak (Higham et al. 2014).

\section{CONCLUSION}

The recent research at Prei Khmeng, in conjunction with that undertaken by the MAFKATA team, has exposed a total of 20 mortuary contexts and evidence of later activity relating to the establishment of a religious sanctuary. The site appears to have been continuously occupied from the Iron Age until the early historic period and while site use beyond the twelfth century is indefinite, it was reoccupied by the nineteenth century.

Bioarchaeological examination of the individuals interred in the Iron Age deposits reveal evidence for intentional dental modification and the demonstration of skeletal trauma in two individuals. The mortuary assemblage accompanying the individuals interred at the site include items such as iron implements, exotic glass and stone beads, metal jewellery, domestic and high-fired ceramic vessels, and faunal offerings. The material culture assemblage from burial and occupation deposits suggests the community engaged in expansive regional trade and interaction networks, with variation between type and quantity of grave goods accompanying the interments indicative of differential wealth or status of some individuals.

The Iron Age of mainland Southeast Asia can be characterized as a period of increasing socio-political complexity prior to the rise of the Angkor state. The manifestation of this complexity is evinced by intensified agricultural production, expanding mercantile activity and interaction spheres, social differentiation, increasing social conflict, and changes in site morphology. Such transformations can be seen at Prei Khmeng and contemporary Iron Age sites in Cambodia and Northeast Thailand. Near Prei Khmeng, at the Iron Age site of Lovea, in the immediate envrions of what was to later become the centre of the Khmer empire, evidence for rudimentary hydraulic engineering in the form of multiple moats and embankments can be seen. Evidence for water management is also present at Prei Khmeng at a later date (perhaps as early as sometime after 500 A.D.), with the creation of a moat surrounding the sanctuary. It is arguable that the temple moat of Prei Khmeng and the moats around Lovea are precursors to the later, large-scale, hydraulic engineering undertakings at Angkor, including the eleventh century Western Baray less than $700 \mathrm{~m}$ from Prei Khmeng. 


\section{ACKNOWLEDGMENTS}

The authors would like to gratefully acknowledge the participation and acquiescence of the people of Prei Khmeng, the APSARA Authority, and the Government of Cambodia for their generous support and cooperation, including Bun Narith, Ros Borath, Mao Larr, and especially our close collaborators, Tan Boun Suy, Dr. Tin Tina, An Sopheap, Kim Samnang, Im Sokrithy, Ea Darith, and Chhay Rachana. Also gratitude to Tho Thon and Sieng Rosath, both of whom made an invaluable contribution to this effort. Thanks also to the International Center of Research and Documentation of Angkor, Department of Conservation of Monuments and Preventative Archaeology. We thank the Australian Research Council for supporting the research through the Discovery Grants programme under grant DP110101997. We are grateful for the support of our colleagues in the field, Suy Pov in particular, and our volunteers and students including Lauren Whiteford. Thanks also to the staff of the Robert Christie Research Center for their support, especially So Malay.

\section{NOTES}

1. The available dates did not include data on the provenance, material dated, calibration curve used, nor the uncalibrated dates and are therefore only estimates gleaned from the histograms (Pottier, Bolle et al. 2009).

2. The dates from each burial with more than one date were modelled separately to arrive at a "date" for each interment. These dates, calculated using the Charcoal Plus Outlier Model, were included in a Bayesian model of all the burials replacing the individual radiocarbon dates from the burials (Ramsey 2017; Reimer et al. 2013).

3. The placement of a Hindu temple atop an area previously used for mortuary purposes is curious given the stringent requirements surrounding the purity of location mentioned in texts such as the Mayamata (Dagens 1995). One might presume either that those who constructed the temple were unaware of the area's use as a cemetery or that Indian conventions regarding the sanctity of the ground were not an important consideration. The former explanation is dubious since burials were found on the temple mound and on the other side of the moat excavated around the temple and it is apparent that the material excavated to create the moat was used to build the temple mound (Penny et al. 2007).

\section{REFERENCES CITED}

AshKenAzy, GARY

2018 Chinese coins, in Primal Trek (website), accessed 25 June 2018. URL: primaltrek.com/ chinesecoins.html.

Bellina, BÉrénice

2003 Beads, social change and interaction between India and South-East Asia. Antiquity 77 (296):285-297.

Carter, Alison

2010 Trade and exchange networks in Iron Age Cambodia: Preliminary results from a compositional analysis of glass beads. Bulletin of the Indo-Pacific Prehistory Association 30:178-188.

2013 Trade, Exchange, and Sociopolitical Development in Iron Age (500 BC-AD 500) Mainland Southeast Asia: An Examination of Stone and Glass Beads from Cambodia and Thailand. Ph.D. diss. University of Wisconsin-Madison, Department of Anthropology.

2015a Preliminary Report on Glass and Stone Beads from Prei Khmeng. Unpublished report to authors.

$2015 b$ Beads, exchange networks and emerging complexity: A case study from Cambodia and Thailand (500 BCE-CE 500). Cambridge Archaeological Journal 25(4):733-757.

Carter, Alison, Phipal Heng, Miriam Stark, Rachna Chhay, and Damian Evans

2018 Urbanism and residential patterning in Angkor. Journal of Field Archaeology 43(6):492-506.

Chrem, Rethy, Venkatesh Sudhakar, Wang Shih-Chang, and Kit-Mui Wong

2004 Multislice computed tomography of two 2000-year-old skeletons in a soil matrix from Angkor, Cambodia. Canadian Association of Radiologists Journal 55(4):235. 
DAGENS, BRUNO

1995 Mayamata: An Indian Treatise on Housing Architecture and Iconography. New Delhi: Sitram Bhartia Institute of Scientific Research.

de Coral-Rémusat, Gilberte

1940 L'art khmer: Les grandes étapes de son évolution [Khmer Art: The Great Stages of its Evolution]. Paris: Études d'art et d'ethnologie asiatiques.

DE LAJONQUiÈre, ÉTIENNE

1911 Inventaire descriptif des monuments du Cambodge [Descriptive Inventory of the Monuments of Cambodia], vol. 3. École française d'Extrême-Orient 9. Paris: EFEO.

Domett, Kate, Jen Newton, Dougald O’Reilly, Nancy Tayles, louise Shewan, and Nancy Beavan

2013 Cultural modification of the dentition in prehistoric Cambodia. Journal of Osteoarchaeology 23:274-286.

Domett, Kate, and Dougald O'Reilly

2009 Health in Pre-Angkorian Cambodia: A bioarchaeological analysis of the skeletal remains from Phum Snay. Asian Perspectives 48(1):56-78.

Domett, Kate, Dougald O'Reilly, and Hallie Buckley

2011 Bioarchaeological evidence for conflict in Iron Age north-west Cambodia. Antiquity 85:441-458.

Feldesman, Marc R., and Robert L. Fountain

1996 "Race" specificity and the femur/stature ratio. American Journal of Physical Anthropology 100 (2):207-224.

Frelat, Mélanie, and Caroline Souday

2015 The Bronze Age necropolis of Koh Ta Meas: Insights into the health of the earliest inhabitants of the Angkor region. Bulletins et mémoires de la Société d'anthropologie de Paris 25:142-157.

Frelat, Mélanie, Caroline Souday, Nicolas Buchet, Fabrice Demeter, and Christophe Pottier

2016 Corrigendum for The Bronze Age necropolis of Koh Ta Meas: Insights into the health of the earliest inhabitants of the Angkor region. Bulletins et mémoires de la Société d'anthropologie de Paris 28:98-99.

Heng, Sophady, Than Heng, Tech Srun, Vuthy Voeurn, and Dany Eam

2013 Kok Treas: Iron Age Mortuary Site at Banteay Meanchey. Phnom Penh: Ministry of Culture and Fine Arts.

Higham, Charles

1994 Chronometric Hygiene and the Bronze Age of Southeast Asia, presented at Congress of the Indo-Pacific Prehistory Association, Chiang Mai, January 1994.

2007 The material culture, in The Origins of the Civilization of Angkor, vol. 2: The Excavation of Noen U-Loke and Non Muang Kao: 353-357, ed. C.F.W. Higham, A. Kijngam, and S. Talbot. Bangkok: Fine Arts Department of Thailand.

2011 The Iron Age of the Mun Valley, Thailand. Antiquaries Journal 91:101-144.

2012a The Iron Age: Domestic occupation, in The Origins of the Civilization of Angkor, vol. 6: The Excavation of Ban Non Wat, part 4: The Iron Age, Summary and Conclusions: 11-30, ed. C.F.W. Higham and A. Kijngam. Bangkok: Fine Arts Department of Thailand.

$2012 b$ The Iron Age: Synthesis, in The Origins of the Civilization of Angkor, vol. 6: The Excavation of Ban Non Wat, part 4: The Iron Age, Summary and Conclusions: 331-370, ed. C.F.W. Higham and A. Kijngam. The Origins of the Civilization of Angkor. Bangkok: Fine Arts Department of Thailand.

2014 Early Mainland Southeast Asia: From First Humans to Angkor. Bangkok: River Books.

Higham, Charles, Judith Cameron, Nigel Chang, Cristina Castillo, Dougald O’Reilly, Fiona Petchey, AND Louise SHewan

2014 The excavation of Non Ban Jak, northeast Thailand: A report on the first three seasons. Journal of Indo-Pacific Archaeology 34:1-41.

Higham, Charles, and Amphan Kijngam, eds.

2012 The Origins of the Civilization of Angkor, vol. 6: The Excavation of Ban Non Wat, part 4: The Iron Age. Bangkok: Fine Arts Department of Thailand. 
Higham, Charles, and Rachanie Thosarat

2006 Ban Non Wat: The first three seasons, in Uncovering Southeast Asia's Past: Selected Papers from the 10th International Conference of the European Association of Southeast Asian Archaeologists: 98-104, ed. I. Glover and V. Piggot. Singapore: National University of Singapore.

Higham, Thomas, Huw Barton, Chris Turney, Graeme Barker, Christopher Bronk Ramsey, and FIONA BROCK

2009 Radiocarbon dating of charcoal from tropical sequences: Results from the Niah Great Cave, Sarawak, and their broader implications. Journal of Quaternary Science 24(2):189-197.

Ikehara-Quebral, Rona, Miriam Stark, William Belcher, Voeun Vuthy, John Krigbaum, Alexander Bentley, Michele Toomay Douglas, and Michael Pietrusewsky

2017 Biocultural practices during the transition to history at the Vat Komnou cemetery, Angkor Borei, Cambodia. Asian Perspectives 56(2):191-236.

KLIMEŠ, ONDř̌J

2004 Xinjiang cast cash in the collection of the Náprstek Museum, Prague. Annals of the Náprstek Museum 25:109-122.

LATinis, Kyle

2004 Prei Khmeng glass beads preliminary EDXRF report, in Mission Archéologique Franco-Khmer sur l'Aménagement du Territoire Angkorien (MAFKATA) [Franco-Khmer Archaeological Mission on the Angkorian Territory (MAFKATA)]: 108-130, ed. C. Pottier. Siem Reap: Ecole française d'Extrême-Orient.

Newton, Jennifer, and Kate Domett

2017 The biocultural context of dental modification in prehistoric Southeast Asia, in $A$ World View of Bioculturally Modified Teeth: 159-181, ed. S. E. Burnett and J. D. Irish. Gainsville: University Press of Florida.

O’Reilly, Dougald

2000 From the Bronze Age to the Iron Age in Thailand: Applying the heterarchical approach. Asian Perspectives 39(1-2):1-19.

2007 Non Muang Kao burials, in The Origins of the Civilization of Angkor, vol. 2: The Excavation of Noen U-Loke and Non Muang Kao: 571-574, ed. C.F.W. Higham, A. Kijngam, and S. Talbot. Bangkok: Fine Arts Department of Thailand.

2008 Multivallate sites and socio-economic change: Thailand and Britain in their Iron Ages. Antiquity 82:377-389.

2014 Increasing complexity and the political economy model: A consideration of Iron Age moated sites in Thailand. Anthropological Archaeology 35:298-309.

O’Reilly, Dougald, Angela von den Driesch, and Vuthy Voeun

2006 Archaeology and archaeozoology of Phum Snay: An Iron Age cemetery in northwest Cambodia. Asian Perspectives 45(2):188-211.

O'Reilly, Dougald, and Louise Shewan

2015a A report on the 2011-2012 excavation of Lovea: An Iron Age moated settlement in Cambodia. Archaeological Research in Asia 1-2:33-47.

2015b The excavation of Phum Sophy 2009-2010: An Iron Age site in northwest Cambodia. Journal of Indo-Pacific Archaeology 39:57-73.

2016 Phum Lovea: A moated precursor to the pura of Cambodia? Socio-political transformation from Iron Age settlements to early state society. Journal of Southeast Asian Studies 47(3):469-484.

$2016 b$ Prehistoric mortuary traditions in Cambodia, in The Routledge Handbook of Bioarchaeology in Southeast Asia and the Pacific Islands: 45-67, ed. M. F. Oxenham and H. Buckley. Oxford: Routledge.

Penny, Dan, Quan Hua, Christophe Pottier, Roland Fletcher, and Michael Barbetti

2007 The use of AMS ${ }^{14} \mathrm{C}$ dating to explore issues of occupation and demise at the medieval city of Angkor, Cambodia. Nuclear Instruments and Methods in Physics Research Section B: Beam Interactions with Materials and Atoms 259(1):388-394.

Pottier, Christophe

2001 Perspectives de la Mission Archéologique Franco-Khmère sur l'Aménagement du Territoire Angkorien [Perspectives of the Franco-Khmer Archaeological Mission on the Angkorian Territory]. Udaya: Journal of Khmer Studies 2:117-132. 
2012 Beyond the temples. Angkor and its territory, in Old Myths and New Approaches: Interpreting Ancient Religious Sites in Southeast Asia: 12-27, ed. A. Haendel. Melbourne: Monash University Publishing.

Pottier, Christophe, Pierre Baty, Fabrice Demeter, and Alexandre Guerin

2003 Mission Archéologique Franco-Khmère sur l'Aménagement du Territoire Angkorien (MAFKATA): Campagne 2003 Rapport [Franco-Khmer Archaeological Mission on the Angkorian Territory (MAFKATA: 2003 Campaign Report)], ed. C. Pottier. Siem Reap: Ecole française d'ExtrêmeOrient.

Pottier, Christophe, and Annie Bolle

2009 Le Prasat Trapeang Phong à Hariharâlaya: Histoire d'un temple et archéologie d'un site [Prasat Trapeang Phong in Hariharâlaya: History of a temple and archaeology of a site]. Aséanie 24:61-90.

Pottier, Christophe, Annie Bolle, Armand Desbat, Chea Socheat, Marie-France Dupoiz, Alice Vierstraete, Adeline Beuken, Evelise Bruneau, and Dan Penny

2009 Mission Archaéologique Franco-Khmèr sur l'Aménagement du Territorie Angkorien (MAFKATA): Campagne 2009 Rapport [Franco-Khmer Archaeological Mission on the Angkorian Territory (MAFKATA): 2009 Campaign Report], ed. C. Pottier. Siem Reap: École française d'ÉxtremeOrient.

Pottier, Christophe, Annie Bolle, Dominique Soutif, Jean Baptiste Chevance, Chea Socheat, Kamsan Heng, Fabrice Demeter, Nicolas Bouchet, Caroline Souday, Mélanie Frelat, Vuthy Voeun, Sonetra Seng, Erwan Dantec, and Maric Beaufeist

2006 Mission Archaéologique Franco-Khmèr sur l'Aménagement du Territorie Angkorien (MAFKATA): Campagne 2006 Rapport [Franco-Khmer Archaeological Mission on the Angkorian Territory (MAFKATA): 2006 Campaign Report], ed. C. Pottier. Siem Reap: École française d'ÉxtremeOrient.

Pottier, Christophe, Alexandre Guerin, Than Heng, Sokrithy Im, Chan Khieu, and Eric Llopis. 2001a Mission Archéologique Franco-Khmère sur l'Aménagement du Territoire Angkorien (MAFKATA). Rapport Preliminaire sur la Campagne de Fouilles [Franco-Khmer Archaeological Mission on the Angkorian Territory (MAFKATA) Report on the Excavation Campaign]. Siem Reap: École française d'Éxtreme-Orient.

$2001 b$ Mission Archéologique Franco-Khmère sur l'Aménagement du Territoire Angkorien (MAFKATA). Rapport sur la Campagne de Fouilles 2000 [Franco-Khmer Archaeological Mission on the Angkorian Territory (MAFKATA)] Report on the Excavation Campaign 2000]. Siem Reap: École française d'Éxtreme-Orient.

Pottier, Christophe, Eric Llopis, Jean Baptiste Chevance, Kong Vireak, Chea Socheat, and Sum SANG

2006 A Bronze Age Necropolis in Angkor, presented at the 11th International Conference of the European Association of Southeast Asian Archaeologists, Bougon, France, September 25-30, 2006.

Ramsey, C. B.

2017 Methods for summarizing radiocarbon datasets. Radiocarbon 59(6):1809-1833.

Reimer, Paula, Edouard Bard, Alex Bayliss, Warren Beck, Paul Blackwell, Christopher Bronk

Ramsey, Caitlin Buck, Hai Cheng, Lawrence Edwards, and Michael Friedrich

2013 IntCal13 and Marine13 radiocarbon age calibration curves 0-50,000 years cal BP. Radiocarbon 55(4):1869-1887.

Reinecke, Andreas, Vin Laychour, and Seng Sonetra

2009 The First Golden Age of Cambodia: Excavation at Prohear. Bonn: Thomas Müntzer.

Sangvichien, Sood J., Vasan Srisurin, and Vebra Watthanayingsakul

1985 Estimation of stature of Thai and Chinese from the length of femur, tibia and fibula. Siriraj Hospital Gazette 37(3):215-218.

SJøvold, Thomas

1990 Estimation of stature from long bones utilizing the line of organic correlation. Human Evolution 5(5):431-447.

SOK, SOVANNARA

2006 Iron Age cemetery site recent excavation in Krasang Thmei village, Banteay Mean Chheay Province, Cambodia, in From Homo Erectus to the Living Traditions: Choice of Papers from the 
11th International Conference of the EurASEAA, Bougon, 25th-29th September 2006: 105-110, ed. J.-P. Pautreau, A.-S. Coupey, V. Zeitoun, and E. Rambault. Chiang Mai: Siam Ratana.

STARK, Miriam

2001 Some preliminary results of the 1999-2000 archaeological field investigations at Angkor Borei, Takeo Province. Udaya: Journal of Khmer Studies 2(1):19-36.

TALBOT, SARAH

2007 The analysis of the mortuary record, in The Origins of the Civilization of Angkor, vol. 2: The Excavation of Noen U-Loke and Non Muang Kao: 305-351, ed. C.F.W. Higham, A. Kijngam, and S. Talbot. Bangkok: Fine Arts Department of Thailand.

Trouvé, GeOrges

1933 Chronique, Cambodge [Chronicle, Cambodia]. Bulletin de l'École française d'Extrême-Orient 33:1125-1128.

\section{ZHOU DAGUAN}

2007 A Record of Cambodia: The Land and Its People, trans. Peter Harris. Bangkok: Silkworm Books.

Zoppi, Ugo, Mike Barbetti, Roland Fletcher, Quan Hua, Rethy Chhem, Christophe Pottier, and MANAS WATANASAK

2004 The contribution of ${ }^{14} \mathrm{C}$ AMS dating to the Greater Angkor archaeological project. Nuclear Instruments and Methods in Physics Research Section B: Beam Interactions with Materials and Atoms 223:681-685. 